\title{
Article \\ Cupriavidus metallidurans CH34 Possesses Aromatic Catabolic Versatility and Degrades Benzene in the Presence of Mercury and Cadmium
}

\author{
Pablo Alviz-Gazitua ${ }^{1,2, \dagger}$, Roberto E. Durán ${ }^{1,+} \mathbb{D}$, Felipe A. Millacura ${ }^{1,3}{ }^{\mathbb{D}}$, Franco Cárdenas ${ }^{1,4}$, Luis A. Rojas ${ }^{5}$ \\ and Michael Seeger $1, *(D)$
}

\section{check for}

updates

Citation: Alviz-Gazitua, P.; Durán, R.E.; Millacura, F.A.; Cárdenas, F.; Rojas, L.A.; Seeger, M. Cupriavidus metallidurans CH34 Possesses Aromatic Catabolic Versatility and Degrades Benzene in the Presence of Mercury and Cadmium. Microorganisms 2022, 10, 484. https://doi.org/10.3390/ microorganisms10020484

Academic Editors: Giovanni Vallini and Silvia Lampis

Received: 22 January 2022

Accepted: 17 February 2022

Published: 21 February 2022

Publisher's Note: MDPI stays neutral with regard to jurisdictional claims in published maps and institutional affiliations.

Copyright: (C) 2022 by the authors. Licensee MDPI, Basel, Switzerland. This article is an open access article distributed under the terms and conditions of the Creative Commons Attribution (CC BY) license (https:// creativecommons.org/licenses/by/ $4.0 /)$.
1 Laboratorio de Microbiología Molecular y Biotecnología Ambiental, Departamento de Química \& Centro de Biotecnología, Universidad Técnica Federico Santa María, Avenida España 1680, Valparaíso 2390123, Chile; alviz.pablo@gmail.com (P.A.-G.); ro.duran.vargas@gmail.com (R.E.D.); f.millacura.a@gmail.com (F.A.M.); soyfranco@gmail.com (F.C.)

2 Departamento de Ciencias Biológicas y Biodiversidad, Universidad de los Lagos, Osorno 5311890, Chile

3 School of Biological Sciences, University of Edinburgh, Edinburgh EH9 3JQ, UK

4 Centro Regional de Estudios en Alimentos Saludables (CREAS), Avenida Universidad 330, Curauma, Valparaíso 2373223, Chile

5 Departamento de Química, Facultad de Ciencias, Universidad Católica del Norte, Avenida Angamos 610, Antofagasta 1270709, Chile; 1.rojas@ucn.cl

* Correspondence: michael.seeger@gmail.com or michael.seeger@usm.cl

+ These authors contributed equally to this work.

\begin{abstract}
Heavy metal co-contamination in crude oil-polluted environments may inhibit microbial bioremediation of hydrocarbons. The model heavy metal-resistant bacterium Cupriavidus metallidurans $\mathrm{CH} 34$ possesses cadmium and mercury resistance, as well as genes related to the catabolism of hazardous BTEX aromatic hydrocarbons. The aims of this study were to analyze the aromatic catabolic potential of $\mathrm{C}$. metallidurans $\mathrm{CH} 34$ and to determine the functionality of the predicted benzene catabolic pathway and the influence of cadmium and mercury on benzene degradation. Three chromosome-encoded bacterial multicomponent monooxygenases (BMMs) are involved in benzene catabolic pathways. Growth assessment, intermediates identification, and gene expression analysis indicate the functionality of the benzene catabolic pathway. Strain $\mathrm{CH} 34$ degraded benzene via phenol and 2-hydroxymuconic semialdehyde. Transcriptional analyses revealed a transition from the expression of catechol 2,3-dioxygenase (tom $B)$ in the early exponential phase to catechol 1,2-dioxygenase (cat $A 1$ and cat $A 2$ ) in the late exponential phase. The minimum inhibitory concentration to $\mathrm{Hg}$ (II) and Cd (II) was significantly lower in the presence of benzene, demonstrating the effect of co-contamination on bacterial growth. Notably, this study showed that $\mathrm{C}$. metallidurans $\mathrm{CH} 34$ degraded benzene in the presence of $\mathrm{Hg}$ (II) or Cd (II).
\end{abstract}

Keywords: Cupriavidus metallidurans; aromatic catabolism; benzene; mercury; cadmium; bacterial multicomponent monooxygenase

\section{Introduction}

Benzene, toluene, ethylbenzene, and xylene isomers, commonly known as BTEX, are volatile monoaromatic hydrocarbons often present in crude oil spilled sites and polluted industrial areas [1,2]. These compounds can easily spread to distant locations from their original locations, polluting natural water bodies, groundwater, and atmospheric air [3]. BTEX are hazardous to living organisms; their toxicity, mutagenicity, and carcinogenic effects increase during bioaccumulation in animal and human tissues. Benzene is the most unsafe and toxic component of this group, causing cancer and leukemia in humans [4]. BTEX are also toxic for microorganisms, disturbing the cell membranes, disrupting the electron transport systems, and provoking oxidative stress damage [2,5]. 
In polluted sites, bacteria are often exposed to a complex scenario wherein co-contamination of hydrocarbons and heavy metal ions may reduce the degradation potential of bacterial strains and effectiveness of the bioremediation process [6-12]. Aerobic bacterial degradation of hydrocarbons may be inhibited by heavy metals such as mercury and cadmium [6,13-16]. Cadmium is a by-product of non-ferrous metal ore processing, a component of battery manufacturing, and a plastic stabilizer $[17,18]$. Mercury has been extensively used in gold extraction by amalgam and is released from heavy metal mining (e.g., copper, silver, and gold) and industrial activities [11,19-21]. BTEX biodegradation in the presence of cadmium and mercury has barely been studied. Cd (II) was found to cause inhibition of toluene, ethylbenzene, and $o$-xylene degradation by Bacillus sp. [22], while limited studies have assessed the role of $\mathrm{Hg}$ on BTEX bacterial catabolism. Cadmium and mercury are toxic for microorganisms and may affect their bioremediation capabilities, mainly through the binding to sulfhydryl groups (cysteine and methionine) and substitutive metal binding to metalloproteins [8,22-25].

Diverse Cupriavidus strains are attractive candidates for bioremediation under adverse conditions, due to their aromatic compound catabolic versatility and heavy metal resistance [26-32]. Cupriavidus pinatubonensis JMP134 is a model strain for the degradation of chloroaromatics, chlorophenols, halobenzoates, nitrophenols, and 2,4-D, exhibiting a wide enzymatic machinery to overcome aromatic compounds in the environment [27]. Cupriavidus necator NH9 is capable of degrading 3-chlorobenzoate (3-CBA) [31], while the biphenyl and chlorpyrifos degraders Cupriavidus basilensis KF708 and Cupriavidus nantongensis X1 have also recently been characterized [29,33]. The recombinant strain Cupriavidus pinatubonensis JMS34 has been patented for the bioremediation of polychlorobiphenyls (PCBs) [34]. On the other hand, Cupriavidus metallidurans strains possess resistance to a broad range of heavy metals and have been applied in mercury bioremediation trials, whereas specific strains exhibit growth on aromatic compounds $[11,21,25,35,36]$.

C. metallidurans $\mathrm{CH} 34$ is a model heavy metal-resistant bacterium isolated from a zinc decantation tank factory sediment. Strain $\mathrm{CH} 34$ harbors a genome composed of four replicons: one chromosome $(\mathrm{C} 1)$, one chromid $(\mathrm{C} 2)$, and two large plasmids (pMOL28 and pMOL30) [35,37-39]. Both megaplasmids carry the genetic determinants for heavy metal resistance, including the mer genes involved in mercury detoxification and cadmium resistance $[39,40]$. The metabolically modified strain C. metallidurans strain MSR33 has been patented for the bioremediation of sites polluted with mercury, cadmium, and copper [41]. Furthermore, diverse catabolic gene clusters have been reported in Cupriavidus genomes $[31,39,42-44]$, including the genomic island CMGI-2 responsible for toluene degradation in C. metallidurans CH34 [30]. Previous studies have predicted the CH34 catabolic potential to grow on monoaromatic compounds (i.e., benzene, toluene, $o$-xylene, phenol, vanillate, $L$-tyrosine, 4-hydroxyphenylacetate), but only its growth on toluene, benzoate, 4-hydroxybenzoate, $L$-tyrosine, vanillate, phenylacetate, and phenylpyruvate have been experimentally reported $[30,36,39,44-47]$.

Genomic analyses of Cupriavidus metallidurans strain $\mathrm{CH} 34$ revealed three bacterial multicomponent monooxygenases (BMM), which are a rare trait and may lead to new mixed or hybrid BMM with novel substrate specificities [48]. The aims of this study were to analyze the aromatic catabolic potential of $C$. metallidurans $\mathrm{CH} 34$ and to determine the functionality of the predicted benzene catabolic pathway and the influence of cadmium and mercury on benzene degradation.

\section{Materials and Methods}

\subsection{Chemicals}

Benzene, toluene, phenol, 3-hydroxyphenylacetate (3-HPA), 4-hydroxyphenylacetate (4$\mathrm{HPA}), \mathrm{HgCl}_{2}$, and $\mathrm{CdCl}_{2}$ of analytical grade were obtained from Merck (Darmstadt, Germany). Benzoate (BA), 3-chlorobenzoate (3-CBA), 4-chlorobenzoate (4-CBA), 3,5-dichlorobenzoate (3,5-CBA), 2-hydroxybenzoate (salicylate), 3-hydroxybenzoate (3-HBA), 4-hydroxybenzoate (4-HBA), 4-isopropylbenzoate ( $p$-cumate), vanillin, cinnamate, $L$-phenylalanine, phenylacetate, anthranilate, 4-aminobenzoate ( $p \mathrm{ABA})$, benzamide, nitrobenzene, catechol, gallate, 
hydroxyquinol (HQ), $p$-cymene (>98\% purity), ethylbenzene, $o$-xylene, $m$-xylene, $p$-xylene, and sodium succinate were obtained from Sigma-Aldrich (St. Louis, MO, USA).

\subsection{Bacterial Strains and Culture Conditions}

C. metallidurans CH34 [37] and Pseudomonas putida F1 [49] were cultivated in lowphosphate Tris-buffered mineral salts (LPTMS) medium at $30^{\circ} \mathrm{C}$. The LPTMS medium contained (per $1 \mathrm{~L}$ ) $6.06 \mathrm{~g}$ Tris, $4.68 \mathrm{~g} \mathrm{NaCl}, 1.07 \mathrm{~g} \mathrm{NH}_{4} \mathrm{Cl}, 1.49 \mathrm{~g} \mathrm{KCl}, 0.43 \mathrm{~g} \mathrm{Na}_{2} \mathrm{SO}_{4}, 0.2 \mathrm{~g}$ $\mathrm{MgCl}_{2} \times 6 \mathrm{H}_{2} \mathrm{O}, 0.03 \mathrm{~g} \mathrm{CaCl}_{2} \times \mathrm{H}_{2} \mathrm{O}, 0.23 \mathrm{~g} \mathrm{Na}_{2} \mathrm{HPO}_{4} \times 12 \mathrm{H}_{2} \mathrm{O}, 0.005 \mathrm{~g} \mathrm{Fe}(\mathrm{III}) /(\mathrm{NH} 4)$ citrate, and $1 \mathrm{~mL}$ of trace element solution SL7 of Biebl and Pfennig [35,37]. Succinate $(6.2 \mathrm{mM})$, benzene $(5 \mathrm{mM})$, or other aromatic compounds $(2 \mathrm{mM})$ were used as sole carbon and energy sources, provided directly in the liquid phase unless otherwise indicated. To avoid BTEX and $p$-cymene volatilization, we closed tubes or flasks using PTFE/siliconescrew caps (DURAN Group GmbH, Wertheim, Germany).

\subsection{Growth of C. metallidurans CH34 on Benzene and Other Aromatic Compounds}

For benzene and aromatic compound growth experiments, $\mathrm{CH} 34$ cells grown in LPTMS medium on succinate (overnight culture), washed twice with $\mathrm{NaCl} 0.85 \% p / v$ and suspended in saline solution $\mathrm{NaCl} 0.85 \% p / v$, were used as inoculum. Growth was followed by measuring the turbidity at $600 \mathrm{~nm}$.

Strain CH34 was cultured in LPTMS medium using benzene $(5 \mathrm{mM})$ as the sole carbon and energy source in $250 \mathrm{~mL}$ flasks with PTFE/silicone-screw caps at $150 \mathrm{rpm}$. These cultures were carried out after an adaptation protocol consisting in successive passages in LPTMS medium using $0.5 \mathrm{mM}$ and $2.0 \mathrm{mM}$ benzene using succinate-grown cells as initial inoculum $(1 \% v / v$, initial turbidity $600 \mathrm{~nm} \approx 0.006)$. Strain $\mathrm{CH} 34$ growth on benzene was determined by measuring turbidity at $600 \mathrm{~nm}$. Values were calculated as the mean $\pm \mathrm{SD}$ of the results of at least three independent experiments.

Growth on other aromatic compounds (toluene, ethylbenzene, xylenes, $p$-cymene, phenanthrene, anthracene, nitrobenzene, BA, 3-CBA, 4-CBA, 3,5-CBA, salicylate, 3-HBA, 4-HBA, $p \mathrm{ABA}$, anthranilate, $p$-cumate, PA, 3-HPA, 4-HPA, vanillin, cinnamate, gallate, $m$-toluate, and $\mathrm{HQ}$ ) was assessed in fresh LPTMS using each compound ( $2 \mathrm{mM})$ as sole carbon and energy source and succinate-grown cells as inoculum $(1 \% v / v$, initial turbidity $600 \mathrm{~nm} \approx 0.006)$. Growth was assessed every $24 \mathrm{~h}$ for 7 days by measuring turbidity $600 \mathrm{~nm}$.

During growth on some aromatics, bacterial aggregation was identified by naked-eye observation. For BTEX compounds and $p$-cymene, growth by $\mathrm{CH} 34$ cells was also assessed in LPTMS agar plates containing sterile-filter papers soaked with each compound placed on the inside cover plate to supply the hydrocarbon via vapor-phase. Values were calculated as the mean $\pm \mathrm{SD}$ of the results of at least three independent experiments.

\subsection{Aromatic Catabolism Reconstruction of C. metallidurans Strain $\mathrm{CH} 34$}

C. metallidurans $\mathrm{CH} 34$ genome was retrieved from NCBI (Accession N ${ }^{\circ}$ GCA_000196015.1). A curated dataset of catabolic enzymes (ring-hydroxylating oxygenases, multicomponent monooxygenases, extradiol, and intradiol dioxygenases) involved in aromatic compound catabolism reported in UniProtKB-Swissprot, EAWAG, KEGG, and scientific literature were analyzed in $\mathrm{CH} 34$ genome using a best-bidirecctional hit $(\mathrm{BBH})$ approach with the BLASTP and TBLASTN tools of BLAST 2.7.1. software [50]. An identity $\geq 30 \%$, coverage $\geq 70 \%$, and e-value cut-off $\leq 1 \times 10^{-10}$ were used as a filter for gene identification. The genomic context of each gene identified was analyzed to identify a complete aromatic catabolic pathway. Missing enzymes of an incomplete pathway were manually searched on the $\mathrm{CH} 34$ genome using the same BBH approach and filter parameters.

\subsection{Comparative and Phylogenetic Analysis of Bacterial Multicomponent Monooxygenase (BMM) Gene Clusters \\ The organization of BMM gene clusters involved in the BTEX degradation by C. metallidurans $\mathrm{CH} 34$ was compared with reported BTEX-degrading bacteria $[27,51-56]$.}


Nucleotide sequences of BMM gene clusters (dmp, phh, phl, phy, aph, tbm, tbc, tbu, tom, tmo, and $t b c$ gene clusters) were retrieved from the GenBank database (Table S1). In some cases, the information was updated with genomic data. BMM gene clusters were aligned and organized according to the phylogenetic relationship of the oxygenase large subunit and the most divergent sequence ( $p h y C, d m p N, t b m D, p h l N$, aphN, tomA3, tomE, tbuA2, tbc2E). Amino acid sequences were aligned using MAFFT version 7.407 [57] and manually trimmed using Aliview version 1.24 [58]. A Bayesian inference phylogenetic mid-rooted tree was obtained using MrBayes 3.2.6 (250,000 generations, two chains each run; sampling every 1000 generations) [59]. Visualization and editing of phylogenetic trees were performed using the FigTree v.1.4.2 software (http:/ / tree.bio.ed.ac.uk/software/figtree/, accessed on 21 March 2020). Bootstrap values (percentage) above $50 \%$ are shown for each branch point.

\subsection{RNA Isolation and Gene Expression Analysis}

Total RNA was isolated from $C$. metallidurans $\mathrm{CH} 34$ cells grown until early exponential

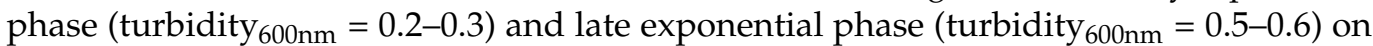
benzene $(5 \mathrm{mM})$ or succinate $(6.2 \mathrm{mM})$ using the RNeasy mini kit (Qiagen, Hilden, Germany) according to the manufacturer's recommendations. TURBO DNAfree set (LifeTechnologies, Carlsbad, CA, USA) was used to degrade residual DNA. A final qPCR test with the gyrB gene primers designed by Primer 3.0 (Table S2) was performed to confirm genomic DNA absence. The RNA concentration was quantified using a Qubit fluorometer (Invitrogen, Carlsbad, CA, USA) and a Nanodrop spectrophotometer (Thermo Scientific, Carlsbad, CA, USA). RNA integrity was observed by agarose (1\%) gel electrophoresis.

Reverse transcription was carried out using $200 \mathrm{ng}$ of RNA and a High Capacity cDNA Reverse Transcription Kit (Applied Biosystems, Foster City, CA, USA). The Minimum Information for Publication of Quantitative Real-Time PCR Experiments (MIQE) guideline was used as standard protocol [60]. Real-time PCR was performed using $20 \mathrm{ng}$ of cDNA on a StepOne Real-Time PCR System (Applied Biosystems, Foster City, CA, USA), using Maxima SYBR Green/ROX qPCR Master Mix (Thermo Scientific, Carlsbad, CA, USA) and $0.3 \mu \mathrm{M}$ of each primer. cDNA was initially denatured at $95^{\circ} \mathrm{C}$ for $5 \mathrm{~min}$. A 40 cycle amplification and quantification protocol $\left(95^{\circ} \mathrm{C}\right.$ for $15 \mathrm{~s}, 55^{\circ} \mathrm{C}$ for $15 \mathrm{~s}$, and $60^{\circ} \mathrm{C}$ for $15 \mathrm{~s}$ ) with a single fluorescence measurement per cycle followed by a melting-curve program $\left(95^{\circ} \mathrm{C}\right.$ for $15 \mathrm{~s}, 25^{\circ} \mathrm{C}$ for $1 \mathrm{~s}, 50{ }^{\circ} \mathrm{C}$ for $15 \mathrm{~s}$, and $95^{\circ} \mathrm{C}$ for $1 \mathrm{~s}$ ) were used according to the manufacturer's recommendations. PCR melting curves confirmed the amplification of a single product for each primer pair. Primers yielded products between 200 and $250 \mathrm{bp}$. The $g y r B$ gene (RMET_RS00030) was amplified as a reference gene, yielding an amplicon of $233 \mathrm{bp}$. A standard curve was made in triplicate using serial dilutions (10-fold) for each amplicon in a linear range (10 ng-0.1 pg) of genomic DNA. qPCR efficiencies were calculated from the slopes of the log-linear portion of calibration curves by using the equation $\mathrm{E}=10(1 /$ slope $)$. The reference $g y r B$ gene was stably expressed according to the algorithms of BestKeeper [61]. Relative gene expression ratios were determined as outlined by Pfaffl (2001) [62], thereby normalizing gene expression levels of CH34 cells grown on benzene versus cells grown on succinate.

\subsection{Determination of Mercury and Cadmium Minimum Inhibitory Concentrations}

The resistance to mercury and cadmium for strains CH34 and F1 was determined by the value of minimum inhibitory concentration (MIC) of metals that prevent growth [35,37]. In order to assess MIC of C. metallidurans $\mathrm{CH} 34$ and P. putida F1 using succinate as sole carbon and energy source, we grew the cells until the late exponential phase in LPTMS medium using succinate $(6.2 \mathrm{mM})$ as a carbon source and inoculated them in fresh LPTMS medium at the same succinate concentration at initial turbidity $600 \mathrm{~nm}=0.06$. On the other hand, for MIC determination using benzene $(5 \mathrm{mM})$ as the sole carbon source, the cells were subjected to a previous adaptation protocol to induce the expression of the catabolic machinery prior to heavy metal exposure. This adaptation consisted of benzene exposure to succinate-grown cells, as previously described, inoculating the cells in fresh LPTMS with 
benzene $(1 \mathrm{mM})$ and $12 \mathrm{~h}$ incubation under the same culture conditions. Benzene-adapted cells were subsequently washed twice using $\mathrm{NaCl}(0.85 \% \mathrm{p} / v)$ and Tween $20(0.05 \% v / v)$ in order to eliminate remaining benzene and inoculated in fresh LPTMS medium using benzene $(5 \mathrm{mM})$ as the sole carbon and energy source to reach an initial turbidity ${ }_{600} \mathrm{~nm}=0.006$ in glass tubes closed using PTFE/silicone-screw caps. Succinate and benzene-grown cells were exposed to increasing concentrations of $\mathrm{Hg}$ (II) or Cd (II) from stock solutions of $\mathrm{HgCl}_{2}$ and $\mathrm{CdCl}_{2}$. Data were collected after $48 \mathrm{~h}$ at $30^{\circ} \mathrm{C}$. Values were determined using at least three independent biological replicates.

\subsection{Benzene Degradation Assays}

Benzene degradation assays were performed using borosilicate glass tubes $(25 \mathrm{~mL})$ with PTFE/silicone-screw caps and arranged in horizontal position. Glass tubes were equilibrated with $1.25 \mathrm{~mL}$ of resting cell buffer (Tris-Cl $50 \mathrm{mM}$ (pH 7.0), Tween20 (0.05\% $v / v)$ ) supplemented with benzene $(10 \mathrm{mM})$ for $12 \mathrm{~h}$ under culture conditions at $30^{\circ} \mathrm{C}$. Tween $20(0.05 \% v / v)$ was added to increase bioavailability in buffer solution and mitigate volatilization. C. metallidurans $\mathrm{CH} 34$ and P. putida $\mathrm{F} 1$ cells were subjected to the benzene adaptation protocol described in Section 2.7. Washed cells were concentrated to obtain a cell suspension at turbidity ${ }_{600 \mathrm{~nm}}=10$ in the resting cell buffer. Aliquots of $1.25 \mathrm{~mL}$ of cell suspensions were added to the benzene-equilibrated glass tubes, resulting in a $2.5 \mathrm{~mL}$ resting cell suspension at turbidity ${ }_{600 \mathrm{~nm}}=5.0$ and benzene $(5 \mathrm{mM})$. Final concentrations of $\mathrm{Hg}$ (II) and Cd (II) were obtained after the addition of aliquots from $\mathrm{HgCl}_{2}$ and $\mathrm{CdCl}_{2}$ $100 \times$ stock solutions. Samples $(100 \mu \mathrm{L})$ were taken at $3 \mathrm{~h}$ intervals during $24 \mathrm{~h}$ of incubation at culture conditions. Cells were removed by centrifugation $(19,000 \times g$ for $1 \mathrm{~min})$ for subsequent analyses of benzene and their metabolites by high-performance liquid chromatography coupled to a diode array detector (HPLC-DAD) and spectrophotometry. A boiled cell suspension was used as a dead cell control to determine abiotic loss of benzene. Cells were killed by boiling for $10 \mathrm{~min}$ in a water bath. Resting cells assays were performed in triplicate, and values were calculated as the mean $\pm \mathrm{SD}$ of the results of at least three independent experiments.

HPLC-DAD analysis was carried out using a Jasco HPLC model LC-2000 equipped with a diode array detector (DAD) Jasco model MD-2015 using a RP 18e/Chromolith column of 100-4.6 mm and a pore size of $13 \mathrm{~nm}$ (Merck, Darmstadt, Germany). The solvents used for sample elution were $0.1 \%$ formic acid in water $(\mathrm{A})$ and $100 \%$ acetonitrile (B). The flow rate was $1.0 \mathrm{~mL} / \mathrm{min}$, and the elution profile was $70 \% \mathrm{~A} / 30 \% \mathrm{~B}$ for $4 \mathrm{~min}$, then changed linearly to $0 \% \mathrm{~A} / 100 \% \mathrm{~B}$ over a $1 \mathrm{~min}$ period and kept at this ratio for $3 \mathrm{~min}$ and finally changed linearly to $30 \% \mathrm{~A} / 70 \% \mathrm{~B}$ over $1 \mathrm{~min}$ and kept at this ratio for $2 \mathrm{~min}$. Benzene, phenol, and catechol concentrations were monitored using calibration curves with authentic standards. The injection volume was $10 \mu \mathrm{L}$. Benzene, phenol, and catechol determinations were performed at 200, 270, and $276 \mathrm{~nm}$ wavelengths, respectively.

2-Hydroxymuconic semialdehyde (2-HMS) content was quantified by measuring absorbance at $375 \mathrm{~nm}$ by spectrophotometry using an Infinite 200 TECAN microplate reader (Tecan Group Ltd., Männedorf, Switzerland). The quantification was based on the molar absorption coefficient $3.3 \times 10^{4}$ of 2-HMS [63].

\section{Results}

\subsection{Genome-Based Reconstruction of the Aromatic Catabolism in Strain CH34}

The aromatic catabolism of $C$. metallidurans $\mathrm{CH} 34$ was reconstructed on the basis of its genome and using the genomic information of aromatic-degrading bacteria. $\mathrm{CH} 34$ genome carries 112 genes encoding 10 central and 19 peripheral pathways/reactions (Figure 1). All the genes identified are located on $\mathrm{C} 1$ and $\mathrm{C} 2$, whereas genes for aromatic catabolism were not observed on plamids pMOL28 and pMOL30. Ten aromatic central catabolic pathways were encoded by 65 genes. The aromatic central catabolic pathways include the catechol and protocatechuate branches of the $\beta$-ketoadipate pathway (cat and pca genes), meta-cleavage catechol (tom genes), gallate (gal genes), HQ (pnp 
genes), homogentisate ( $h m g$ genes), 3-hydroxyanthranilate (onb genes), 2-aminobenzoylCoA (abm genes), phenylacetyl-CoA (paa genes), and benzoyl-CoA (box genes) (Table S3). The genes of aromatic peripheral catabolic pathways/reactions comprised chlorobenzoate (ben genes), benzoate (ben and $b c l$ genes), 4-HBA (pob genes), phenylalanine ( $p h h$ genes), tyrosine (tyrB), 2-hydroxyphenylacetate (2-HPA; ohpA), anthranilate ( $a b m G), 3$-hydroxy-Lkynurenine ( $k y n U)$, tryptophan ( $k y n$ genes), 4-hydroxyphenylpyruvate $(h p p D)$, phenylacetate (paaK), coniferyl alcohol (calA), coniferyl aldehyde (calB), ferulic acid (fcs), vanillin $(v d h)$, vanillate and isovanillic acid (iva genes), phenol (phy genes), and BTEX compounds (phy, tmo, and tom genes) (Figure 1, Table S4).

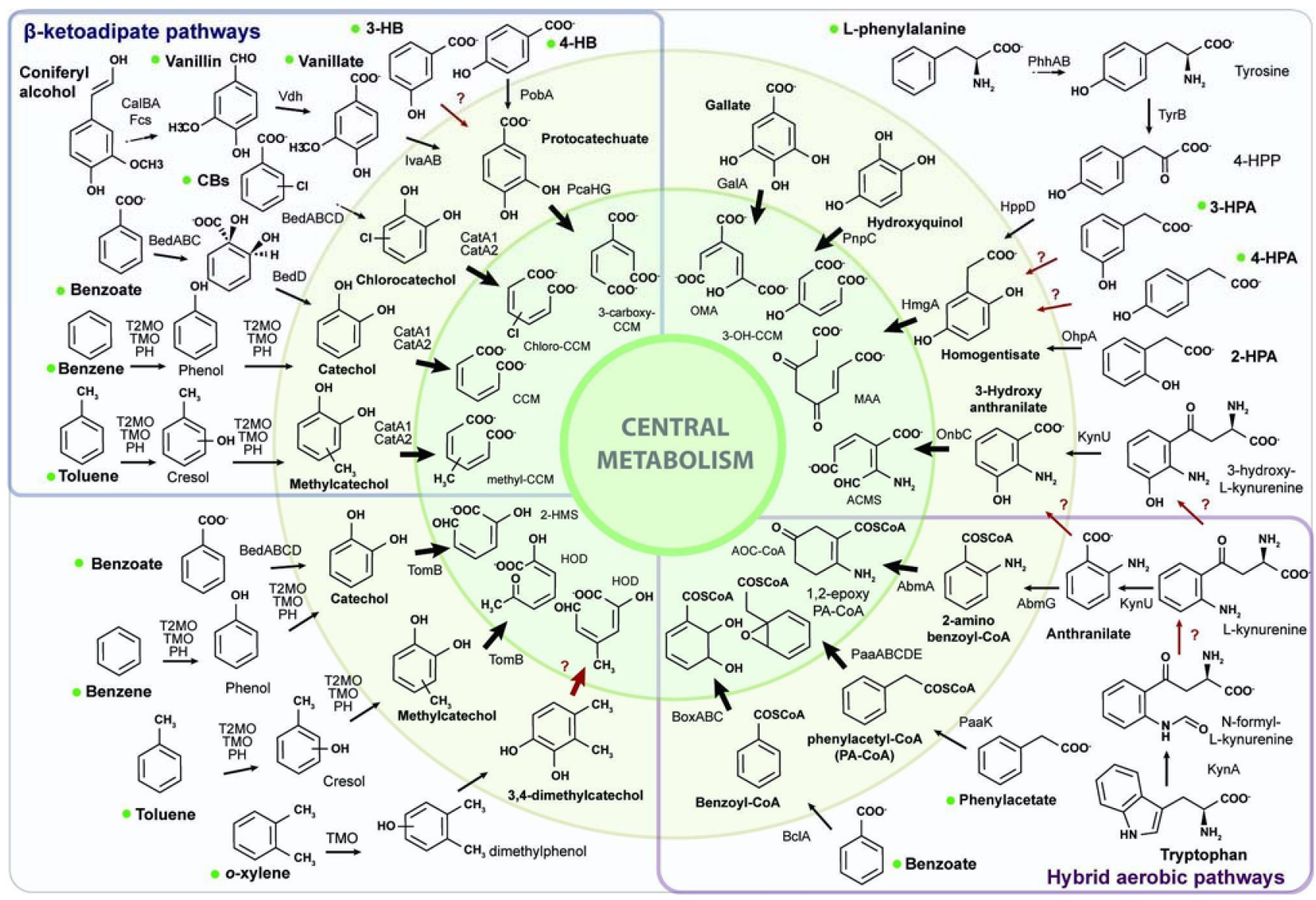

Figure 1. Schematic representation of aromatic peripheral and central catabolic pathways/reactions present in C. metallidurans $\mathrm{CH} 34$. The inner circle (yellow) includes ring cleavage product structures of aromatic central catabolic pathways. The outer circle (blue) includes the structure of dihydroxylated and aryl-CoA ring cleavage intermediates. Dashed arrows indicate multiple steps. Red arrows represent enzymes not encountered in C. metallidurans $\mathrm{CH} 34$ genome. Bacterial growth was observed on peripheral compounds marked with a green dot as the only carbon and energy source.

The genomic islands (GIs) CMGI-1 (RMET_RS11485-RMET_RS12070), CMGI-2 RMET_RSO 6240-RMET_RS06810), and CMGI-E (RMET_RS27890-RMET_RS28445) are the only GIs encoding genes for aromatic peripheral and central catabolic pathways in the $\mathrm{C}$. metallidurans $\mathrm{CH} 34$ genome. The chromosome (C1) of strain $\mathrm{CH} 34$ contains the CMGI-1 locus, which includes a crotonase/enoyl-CoA hydratase-encoding gene (ech) probably involved in the catabolic pathway of hydroxycinnamic acids to the central intermediate protocatechuate (Figure 1). $\mathrm{C} 1$ also harbors CMGI-2, which is related to benzene/toluene catabolism [30,39,44]. CMGI-2 locus is a gene cluster of 24,547 bp encompassed from RMET_RS06580 to RMET_RS06715 (Tables S3 and S4), encoding two bacterial multicomponent monooxygenases (BMMs, tom $A 0 A 1 A 2 A 3 A 4 A 5$ and tmo $A B C D E F)$, one catechol 2,3-dioxygenase (tom $B)$, one transcriptional regulator $(\mathrm{XylR} / \mathrm{NtrC}$ - 
type), a membrane transport protein (TbuX/FadL-type), and seven additional enzymes involved in the central metabolism of catechols and methylcatechols (Figure 2). The chromid (C2) of strain $\mathrm{CH} 34$ possesses only one genomic island (CMGI-E) related to aromatic compound degradation, encoding the genes for an isovanillate/vanillate $O$-demethylase (iva $A B$ ) and 4-hydroxybenzoate3-monooxygenase (pobA2) (Figure 1, Table S4). A total of 27 of the 112 genes identified for aromatic catabolism in C. metallidurans CH34 are present in GIs (Tables S3 and S4).

A

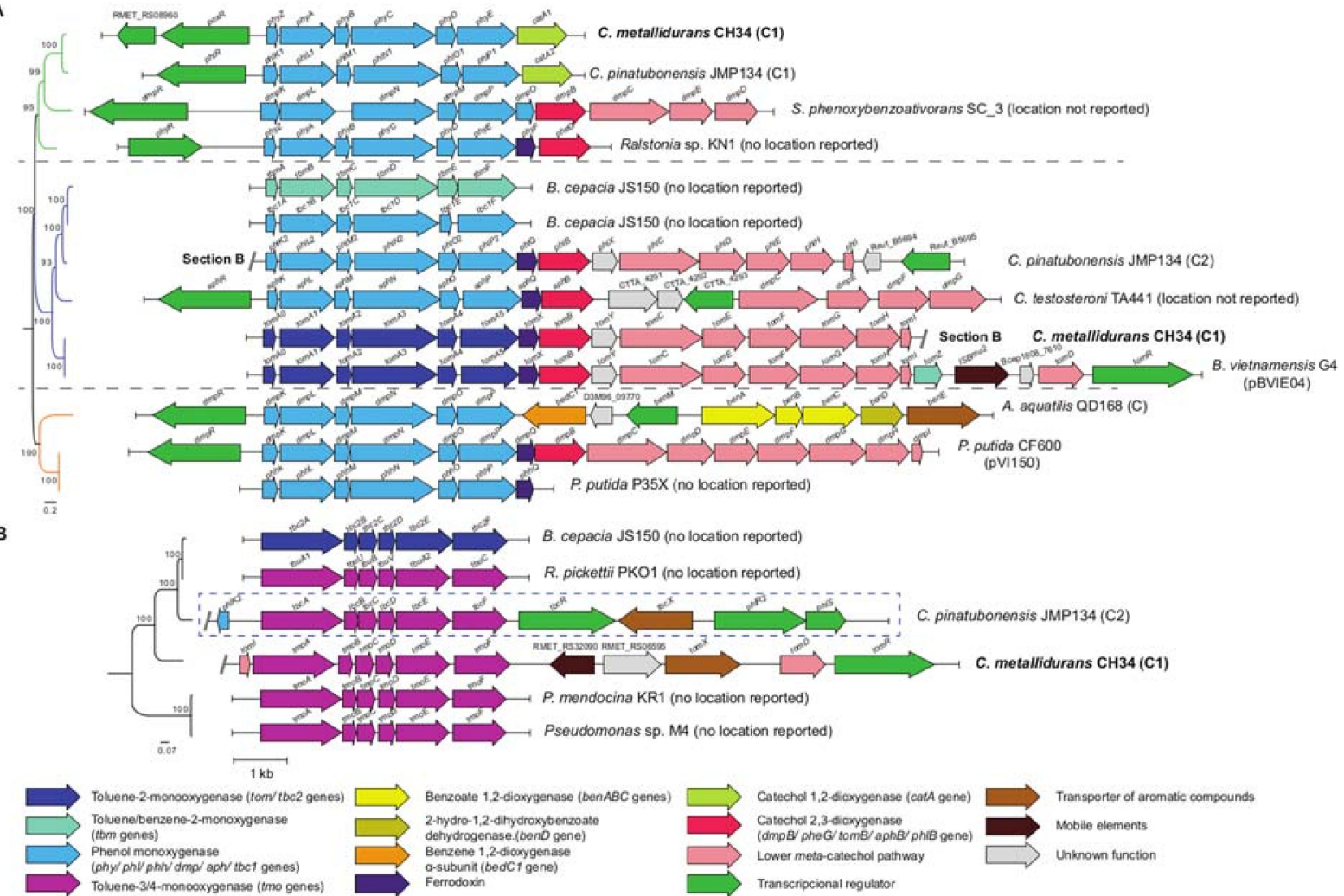

Figure 2. Gene cluster organization of bacterial multicomponent monooxygenases (BMMs) of C. metallidurans $\mathrm{CH} 34$ and other Proteobacteria. BMM gene clusters were classified as described by Notomista et al. (2003) into group I (A) and group II (B) according to the synteny of their hydroxylase components. Each group was further organized by phylogenetic analysis of their most divergent hydroxylase subunit (Bayesian inference method and mid-rooted). The orientations of ORFs are represented by open arrows. Genes and intergenic regions are on scale. (A) BMM gene cluster I. Three clades were identified by phylogenetic analysis of the $\alpha$-hydroxylase subunit (PhyC, PhlN, DmpN, PhyC, TbmD, Tbc1D AphN, and TomA3). Strain CH34 phy and tom gene clusters belonged to clades 1 and 2, respectively. (B) BMM gene cluster II (arranged by $\gamma$-hydroxylase subunit: TmoE, $\mathrm{TbuC}, \mathrm{TbcF}$, and Tbc2F). C. metallidurans $\mathrm{CH} 34$ tmo gene cluster formed a singleton.

A third BMM is located in the $\mathrm{CH} 34$ genome, encoded in a gene cluster of $7587 \mathrm{bp}$ from RMET_RS08920 to RMET_RS08955 between the CMGI-11 and CMGI-6 (Table S4) [40]. This genomic locus comprises a phenol hydroxylase (phyZABCDE), a catechol 1,2-dioxygenase (catA1), and a XylR/NtrC-type transcriptional regulator (poxR) [39]. A phylogenetic analysis of the amino acid sequence of the most divergent oxygenase component from $C$. metallidurans CH34 and other Proteobacteria allowed for the classification of the three BMMs. PhyZABCDE and TomA0A1A2A3A4A5 were classified into group I, whereas TmoABCDEF belonged to the second BMM group (Figure 2). Group I of proteobacterial BMMs was highly represented by phenol hydroxylases (PHs), including two clades completely composed of PHs (green and orange), and wherein PhyC from the phyZACBDE gene cluster was located (Figure 2A). PHs are responsible for phenol and benzene catabolism in other Proteobacteria [50]. The closest sequence to PhyC from strain CH34 is PhlN1, which is part of 
the phl gene cluster of $C$. pinatubonensis JMP134, another gene cluster that also encodes a catechol 1,2-dioxygenase (cat $A$ ) downstream of the operon. A distinct clade inside group I (blue, Figure 2A) formed by the PHs toluene-benzene 2-monooxygenases (TB2MOs) and toluene 2-monooxygenases (T2MOs) contains TmoA3 from strain CH34 (first BMM from the CMGI-2 aromatic gene cluster). The TmoA3 clade is composed of two T2MOs belonging to Burkholderia vietnamiensis $\mathrm{G} 4$ and C. metallidurans $\mathrm{CH} 34$, possessing high synteny and identity between both T2MO gene clusters and the downstream meta-cleavage catechol pathway (tomXBYCEFGHI; Table S4). Interestingly, the B. vietnamensis G4 cluster is located on the plasmid pBVIE04 and carries an ISBmu2-like-insertion sequence (Figure 2A). The last $\mathrm{CH} 34 \mathrm{BMM}$ is also part of the first $24 \mathrm{~kb}$ gene cluster from CMGI-2 and was classified as part of the group II BMMs (Figure 2B). Group II of BMM was composed of broad-substrate monooxygenases such as benzene monooxygenases (BMO), toluene-2-monooxygenases (T2MO), toluene-3-monooxygenases (T3MO), toluene-4-monooxygenases (T4MO), and toluene/o-xylene monooxygenases (ToMO). For example, ToMO oxidizes benzene; toluene; $o$-, $m$ - and $p$-xylene; ethylbenzene; 2,3- and 3,4-dimethylphenol; cresols; naphthalene; TCE; and chloroform [54]. The TmoE $\gamma$-hydroxylase subunit of strain CH34 does not cluster with other known group II BMMs (Figure 2B).

The tmoX (RMET_RS06590) gene, part of the CMGI-2, encodes a TbuX/FadL-type outer membrane transport protein that possesses a $43 \%$ identity with the transporter TmoX of Pseudomonas mendocina KR1, which is part of the toluene X superfamily of mono-aromatic outer membrane transport proteins [64].

\subsection{C. metallidurans CH34 Growth on Aromatic Compounds}

In LPTMS minimal medium, C. metallidurans $\mathrm{CH} 34$ was able to grow on benzene, toluene, $p$-cymene, BA, 3-CBA, 2-hydroxybenzoate (salicylate), 3-HBA, 4-HBA, pABA, PA, 3-HPA, 4-HPA, vanillin, and cinnamate as sole carbon and energy sources (Table 1). Strain CH34 did not exhibit an increase in turbidity600nm in specific recalcitrant aromatic compounds, such as 3,5-CBA, ethylbenzene, and xylenes, but growth as bacterial aggregation was observed. In contrast, strain $\mathrm{CH} 34$ was not able to grow on gallate, phenanthrene, anthracene, nitrobenzene, anthranilate, 4-CBA, $m$-toluate, $p$-cumate, and HQ as sole carbon and energy sources (Table 1). Strain $\mathrm{CH} 34$ tolerated exposure to benzene at concentrations up to its saturation point in water $(20 \mathrm{mM})$.

\subsection{Benzene Catabolism by C. metallidurans $\mathrm{CH} 34$}

The functionality of the benzene catabolic pathway of C. metallidurans $\mathrm{CH} 34$ was evaluated. Benzene was selected as a model BTEX compound due to its environmental relevance, high toxicity, and presence in hydrocarbon-polluted sites. During C. metallidurans $\mathrm{CH} 34$ growth on benzene, at early exponential phase $(22 \mathrm{~h})$, a yellow color formation was observed. The absorbance spectrum of the yellow-colored culture by spectrophotometry indicated the formation of 2-hydroxymuconic semialdehyde (2-HMS) during the metacleavage pathway by the catechol 2,3-dioxygenase (C23O) TomB (Figure 3B).

To identify other metabolic intermediates of the benzene catabolism, we analyzed culture supernatants of $\mathrm{CH} 34$ cells grown on benzene $(5 \mathrm{mM})$ by HPLC-DAD. Benzene concentration decreased during the incubation, while the formation of phenol was detected after 15-26 h (Figure 3B). However, catechol was not detected by HPLC-DAD.

\subsection{Transcriptional Analysis during Benzene Degradation}

The expression of genes encoding the T2MO (tomA3), TMO (tmo A), $\mathrm{PH}(p h y C)$, catechol 1,2-dioxygenase (C12O; cat $A 1$ and cat $A 2), \mathrm{C} 23 \mathrm{O}$ (tom $B)$, semialdehyde-2-hydroxymuconate dehydrogenase $(\operatorname{tom} C)$, and semialdehyde-2-hydroxymuconate hydrolase (tom $D)$ were quantified by RT-qPCR analysis. Transcriptional analysis of CH34 cells grown on benzene as the sole carbon source showed a simultaneous expression of genes encoding monooxygenases in both early and late exponential phase (Figure 4). The tomB, cat $A 1$ and cat $A 2$ genes displayed differential transcriptional expression. The tomB gene encoding $\mathrm{C} 23 \mathrm{O}$ 
was induced at the early and late exponential phases, whereas the cat $A 1$ and cat $A 2$ genes showed a higher induction at the late exponential phase. The tom $C$ and tomD genes were expressed at the early and late exponential phases, suggesting that the hydrolytic and the 4-oxalocrotonate branches of the meta-cleavage pathways are active. In addition, the transcription of the sigma-38 factor rpoS gene, as well as the LysR-type (catM and benM) and the XylR/NtrC-type (tomR and poxR) transcriptional regulators, were studied. The tomR gene encoding a XylR/NtrC-type transcriptional regulator was expressed at early and late exponential phase. Conversely, the sigma-38 factor rpoS gene, and the ben $M$, cat $M$, and poxR genes encoding for transcriptional regulators were expressed only during the late exponential phase (Figure 4). On the basis of these results, we propose that benzene is degraded in $\mathrm{C}$. metallidurans $\mathrm{CH} 34$ by an upper pathway that involves successive monooxygenation reactions catalyzed by the BMMs: $\mathrm{PH}, \mathrm{T} 2 \mathrm{MO}$, and $\mathrm{TMO}$, producing phenol and catechol as metabolic intermediates (Figure 5). The central pathway starts with a meta- or ortho-cleavage by catechol dioxygenases TomB in order to form 2-HMS, or by CatA1 and CatA2 in order to form cis-cis muconate, respectively. Transcriptional data and the metabolite formation suggest a predominant meta-cleavage pathway via $\mathrm{C} 23 \mathrm{O}$, while an induction of the cat $A 1$ and cat $A 2$ genes was observed at a late exponential phase. The induction of the tom $C$ and tom $D$ genes at early exponential phase suggest that both branches of the meta-cleavage pathway are active during benzene degradation (Figure 5).

\subsection{C. metallidurans CH34 and P. putida F1 growth on Benzene in the Presence of Mercury and Cadmium}

To evaluate the effects of mercury and cadmium during growth on benzene, we determined the MICs of $\mathrm{Hg}$ (II) and Cd (II) in C. metallidurans CH34, and the model benzene-degrader P. putida F1. P. putida F1 was incorporated as a model proteobacterium for aerobic benzene degradation [52,65].

The MICs of $\mathrm{Hg}$ (II) and Cd (II) were significantly lower when the strains were previously grown on benzene $(5 \mathrm{mM})$ compared to succinate-grown cells (Table 2). Strain $\mathrm{CH} 34$ showed higher MICs for $\mathrm{Hg}$ (II) than strain F1, independently of the carbon source. For strain F1, the impact of benzene growth on MIC was higher in the presence of $\mathrm{Cd}$ (II) than in presence of $\mathrm{Hg}$ (II), reaching only $10 \%$ of the MIC observed during growth on succinate (Table 2).

\subsection{The Effects of Mercury or Cadmium on Benzene Degradation by C. metallidurans CH34 and P. putida F1}

The effects of mercury $(32.5 \mu \mathrm{M})$ or cadmium $(200 \mu \mathrm{M})$ on benzene degradation by $\mathrm{C}$. metallidurans $\mathrm{CH} 34$ was studied and compared with the degradation by benzenedegrader P. putida F1. The metal ion concentrations were selected after preliminary experiments to determine which concentration caused an inhibitory effect in bacterial catabolism. Benzene degradation is achieved in strain $\mathrm{CH} 34$ via BMMs, while strain $\mathrm{F} 1$ activates the aromatic ring using a benzene/toluene dioxygenase [66]. The benzene, 2-HMS, phenol, and catechol concentrations were monitored in resting cell assays (Figures 6, 7, and S1). The resting cell assay considered an initial concentration of $5 \mathrm{mM}$ of benzene and a cellular turbidity ${ }_{600 \mathrm{~nm}}=5.0$.

In the absence of heavy metals, $\mathrm{C}$. metallidurans $\mathrm{CH} 34$ showed a lower benzene degradation rate in comparison with $P$. putida $\mathrm{F} 1$, which showed no residual benzene with the concomitant highest 2-HMS concentration after $3 \mathrm{~h}$ (Figure 6). A decrease in benzene was observed for dead cells for both strains, indicating abiotic benzene loss from the aqueous phase, probably by volatilization and biosorption. For the resting cell assay of benzene by strain $\mathrm{CH} 34$, phenol was detected at $3 \mathrm{~h}$ (Figure S1), while 2-HMS was detected at $6 \mathrm{~h}$ (Figures 6A and 7A), supporting the proposed benzene degradation pathway in $C$. metallidurans $\mathrm{CH} 34$. 
Table 1. Growth of $\mathrm{C}$. metallidurans $\mathrm{CH} 34$ on aromatic compounds as sole carbon and energy sources.

\begin{tabular}{|c|c|}
\hline Carbon Source & C. metallidurans $\mathrm{CH} 34$ \\
\hline \multicolumn{2}{|l|}{ Monoaromatic hydrocarbons } \\
\hline Benzene & + \\
\hline Toluene $^{\mathrm{a}}$ & + \\
\hline Ethylbenzene & \pm \\
\hline$o$-Xylene & \pm \\
\hline m-Xylene & \pm \\
\hline$p$-Xylene & \pm \\
\hline$p$-Cymene & + \\
\hline \multicolumn{2}{|l|}{ Polycyclic hydrocarbons } \\
\hline Phenanthrene & - \\
\hline Anthracene & - \\
\hline \multicolumn{2}{|l|}{ Benzoates } \\
\hline Benzoate (BA) & ++ \\
\hline 3-Chlorobenzoate (3-CBA) & + \\
\hline 4-Chlorobenzoate (4-CBA) & - \\
\hline 3,5-Dichlorobenzoate (3,5-CBA) & \pm \\
\hline 2-Hydroxybenzoate (salicylate) & +++ \\
\hline 3-Hydroxybenzoate (3-HBA) & +++ \\
\hline 4-Hydroxybenzoate (4-HBA) & +++ \\
\hline 2-Aminobenzoate (anthranilate) & - \\
\hline 4-Aminobenzoate ( $p$ ABA) & ++ \\
\hline 4-Isopropylbenzoate ( $p$-cumate) & - \\
\hline \multicolumn{2}{|l|}{ Phenylacetates } \\
\hline Phenylacetate (PA) & + \\
\hline 3-Hydroxyphenylacetate (3-HPA) & +++ \\
\hline 4-Hydroxyphenylacetate (4-HPA) & ++ \\
\hline Cinnamate & ++ \\
\hline Vanillin & +++ \\
\hline Vanillate & $+{ }^{b}$ \\
\hline \multicolumn{2}{|l|}{ Aromatic amino acids } \\
\hline L-Phenylalanine & ++ \\
\hline$L$-Tyrosine & $+b$ \\
\hline \multicolumn{2}{|l|}{ Other aromatic compounds } \\
\hline Benzamide & - \\
\hline Nitrobenzene & - \\
\hline$m$-Toluate & - \\
\hline Hydroxyquinol (HQ) & - \\
\hline Gallate & - \\
\hline \multicolumn{2}{|l|}{ Other non-aromatic compounds } \\
\hline Succinate & + \\
\hline
\end{tabular}

b David et al. (1996). 
A

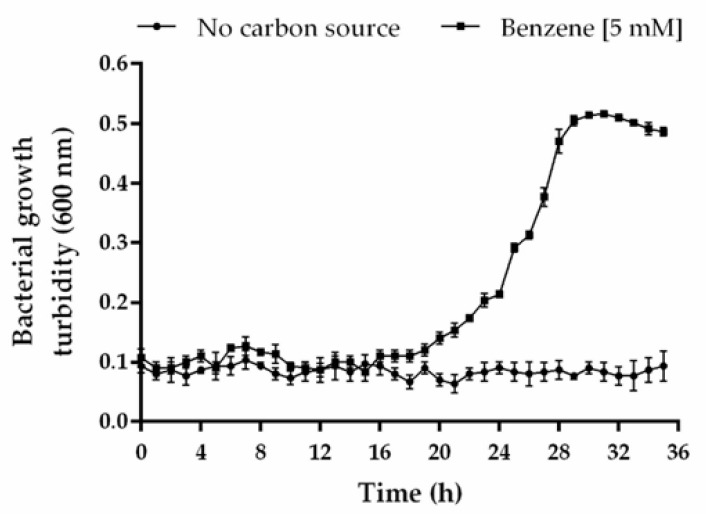

B

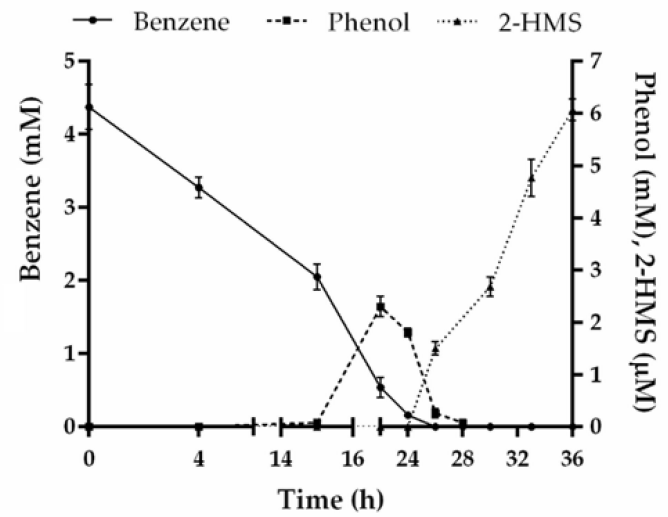

Figure 3. Formation of the metabolic intermediates phenol and 2-hydroxymuconic semialdehyde (2-HMS) during C. metallidurans CH34 growth on benzene. (A) CH34 cells were grown in LPTMS minimal medium using benzene $(5 \mathrm{mM})$ as sole carbon and energy sources. Control assays without carbon source are also depicted. (B) The metabolic intermediates were analyzed by HPLC. Benzene degradation (square), phenol formation (triangle), and the generation of 2-hydroxymuconic semialdehyde (2-HMS; circle) after meta-cleavage of the catechol ring are indicated. Control assays without bacteria showed no degradation (data not shown). Each point is an average \pm SDs of results from at least three independent assays.

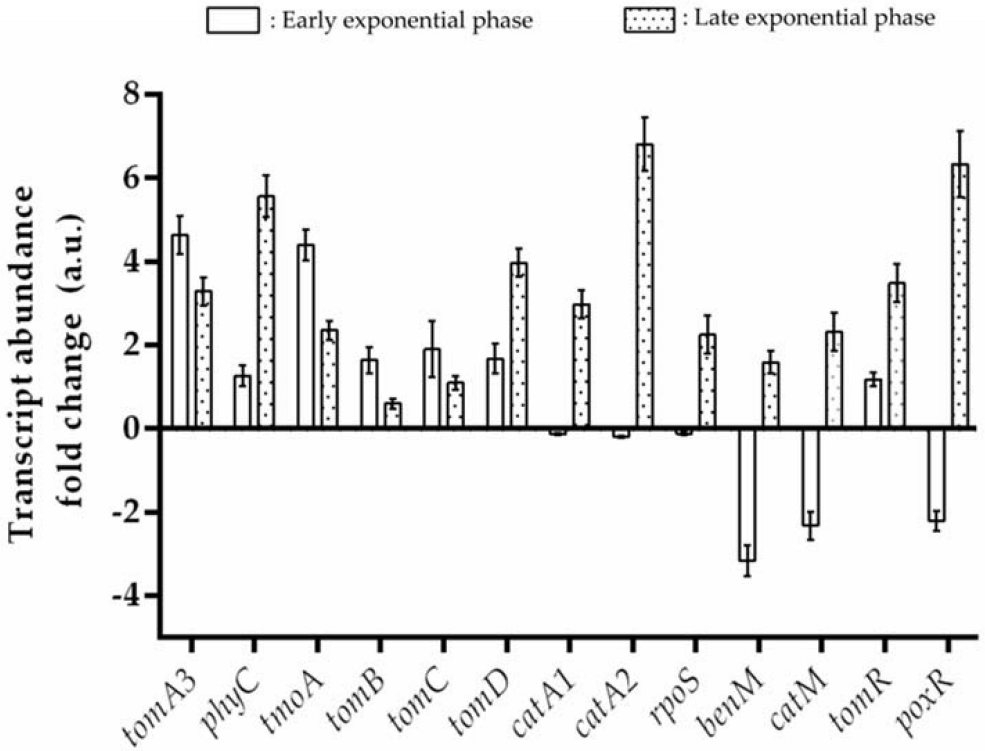

Figure 4. Transcriptional analysis of $C$. metallidurans $\mathrm{CH} 34$ benzene catabolic pathway genes. RTqPCR assays were performed using mRNA from $\mathrm{CH} 34$ cells grown in LPTMS minimal medium supplemented with benzene $(5 \mathrm{mM})$ until early exponential phase (turbidity at $600 \mathrm{~nm}$ of $0.2-0.3$, $\approx 24 \mathrm{~h}$; white column) and late exponential phase (turbidity at $600 \mathrm{~nm}$ of $0.5-0.6 ; \approx 28 \mathrm{~h}$, dotted column). The genes encode for toluene 2-monooxygenase (tom $A 3)$, toluene monooxygenase $(\operatorname{tmo} A)$, phenol hydroxylase (phyC), catechol 2,3-dioxygenase (tomB), catechol 1,2-dioxygenase (cat $A 1$ and catA2), hydroxymuconic semialdehyde dehydrogenase (tom $C)$, 2-hydroxymuconic semialdehyde hydrolase (tomD), sigma factor 38 (rpoS), LysR-type transcriptional regulators (benM and cat M), and $\mathrm{XylR} / \mathrm{NtrC}$-type transcriptional regulators (tomR and poxR). The gyrB gene was used as a reference gene. The primer pairs used are listed in Table S2. The fold-change in gene expression was calculated relative to $\mathrm{CH} 34$ cells grown on succinate. $p$ value $=0.1 \%$. 


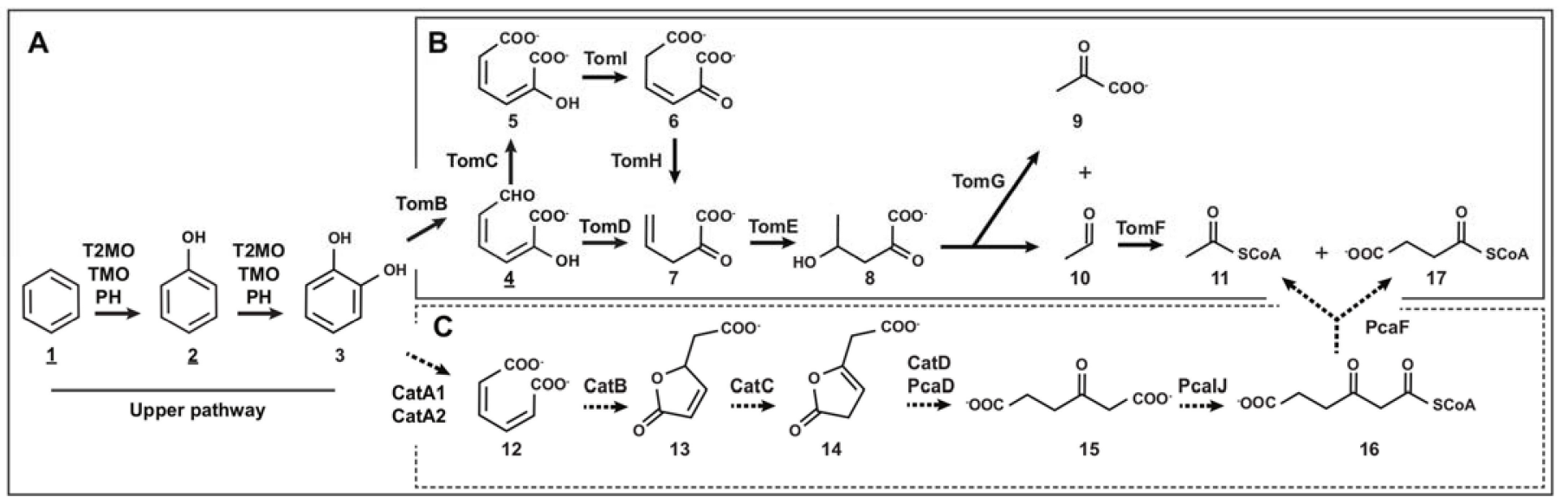

Figure 5. Proposed benzene catabolic pathways in C. metallidurans $\mathrm{CH} 34$. Main pathway for benzene degradation in strain $\mathrm{CH} 34$ is indicated with continuous arrows, whereas the oxidation pathway that was not preferred is indicated with dashed arrows. Intermediate metabolites with experimental data are underlined. (A) Upper pathway for benzene degradation via consecutive monooxygenation. The substrates and products are as follows: 1, benzene; 2, phenol; 3, catechol. The enzymes involved are as follows: T2MO (toluene 2-monooxygenase), TMO (toluene monooxygenase), $\mathrm{PH}$ (phenol hydroxylase). (B) Lower pathway for catechol via meta-cleavage. The substrates and products are as follows: 4, 2-hydroxymuconic semialdehyde; 5, 2-hydroxymuconate; 6, 4-oxalocrotonate; 7, 2-oxopenta-4enoate; 8, 4-hydroxy-2-oxopentanoate; 9 , pyruvate; 10, acetaldehyde; 11 , acetyl-CoA. The enzymes involved are as follows: TomB (catechol 2,3-dioxygenase), TomC (semialdehyde-2-hydroxymuconate dehydrogenase), TomI (4-oxalocrotonate tautomerase), TomH (4-oxalocrotonate decarboxylase), TomD (semialdehyde-2-hydroxymuconate hydrolase), TomE (2-hydroxypent-2,4-dienoate hydratase), TomG (4-hydroxy-2-ketovalerate aldolase), TomF (acetaldehyde-CoA dehydrogenase). (C) Lower pathway for catechol via ortho-cleavage. The substrates and products are as follows: 12, cis-cis muconate; 13, muconolactone; 14, 3-oxoadipate-enol-lactone; 15, 3-oxoadipate; 16, 3-oxoadipyl-CoA; 17, succinyl-CoA. The enzymes involved are as follows: CatA (catechol 1,2-dioxygenase), CatB (muconate cycloisomerase), CatC (muconolactone delta-isomerase), CatD/PcaD (3-oxoadipate enol-lactonase), PcaIJ (3-oxoadipate CoA-transferase), PcaF (3-oxoadipyl-CoA thiolase).

Table 2. Minimal inhibitory concentrations of cadmium and mercury in $C$. metallidurans $\mathrm{CH} 34$ and $P$. putida F1 using succinate or benzene as sole carbon and energy source.

\begin{tabular}{ccccccc}
\hline & \multicolumn{3}{c}{ Mercury $(\mu \mathrm{M})$} & \multicolumn{3}{c}{ Cadmium $(\mathrm{mM})$} \\
\hline Strain & Succinate & Benzene & Fold Change & Succinate & Benzene & Fold Change \\
\hline C. metallidurans CH34 & 12.5 & 2 & 6.25 & 4 & 0.8 & 5 \\
\hline P. putida F1 & 3.25 & 1 & 3.25 & 4 & 0.4 & 10 \\
\hline
\end{tabular}

The presence of mercury or cadmium had no detrimental effects on benzene degradation by C. metallidurans CH34 (Figures 6 and 7, Table S5). Of note, despite a decay in phenol production by both heavy metals (Figure S1), mercury exposure slightly stimulated the benzene degradation, supported by an increase of 2-HMS production at $6 \mathrm{~h}$ incubation (Figure 6A, Table S5). After longer incubation, CH34 2-HMS production rate was lower during $\mathrm{Hg}$ (II) exposure compared to the control condition. In contrast, cadmium slightly inhibited CH34 production of 2-HMS at shorter incubations (6 and $9 \mathrm{~h}$ ), but not after $12 \mathrm{~h}$ (Figure 7A, Table S5). In P. putida F1, the presence of mercury strongly inhibited benzene degradation, showing almost negligible 2-HMS production (Figure 6B, Table S5). Cadmium showed no effect on strain F1 benzene oxidation; however, a slight inhibition in 2-HMS degradation was observed (Figure 7B, Table S5). 
A
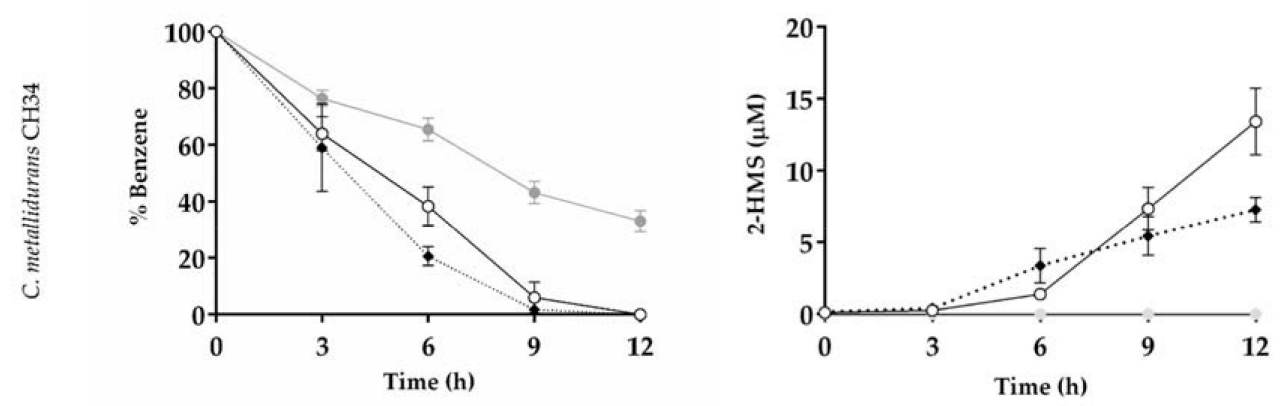

B
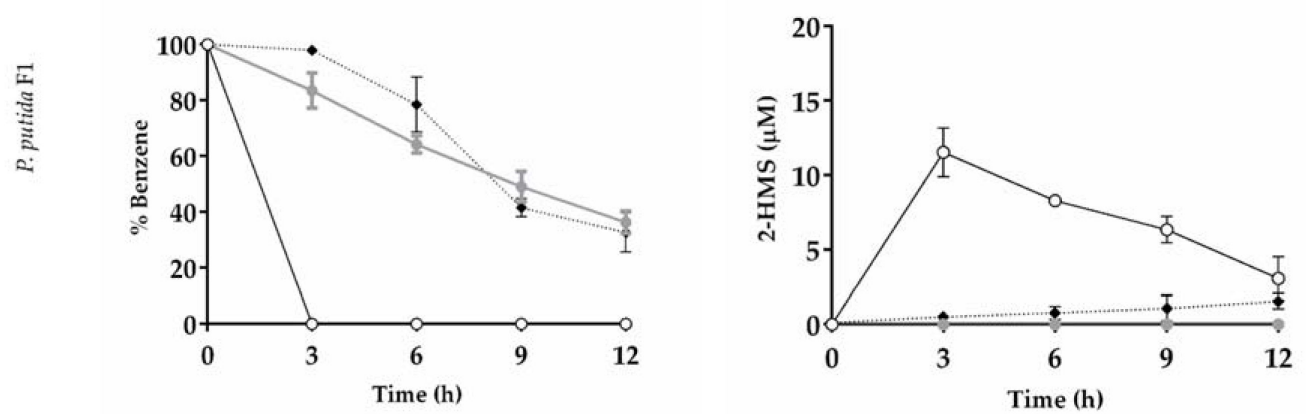

Figure 6. Effects of mercury on benzene degradation $(5 \mathrm{mM})$ and 2-HMS formation by C. metallidurans CH34 and P. putida F1. Effects of $\mathrm{HgCl}_{2}(32.5 \mu \mathrm{M})$ on (A) C. metallidurans CH34 and (B) P. putida F1. Each point is an average \pm SDs of results from three independent resting cell assays.
: Dead cells
$\multimap$ Control
$\rightarrow: \mathrm{CdCl}_{2} 200 \mu \mathrm{M}$

A
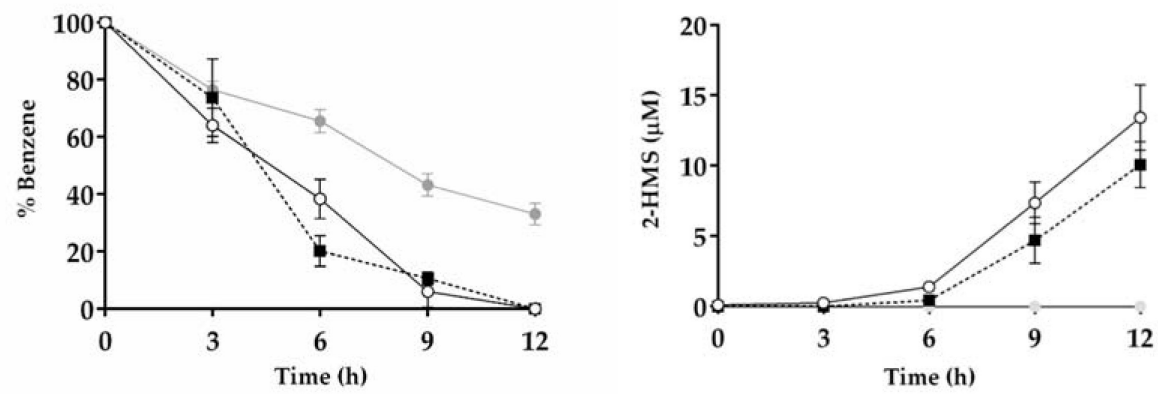

B
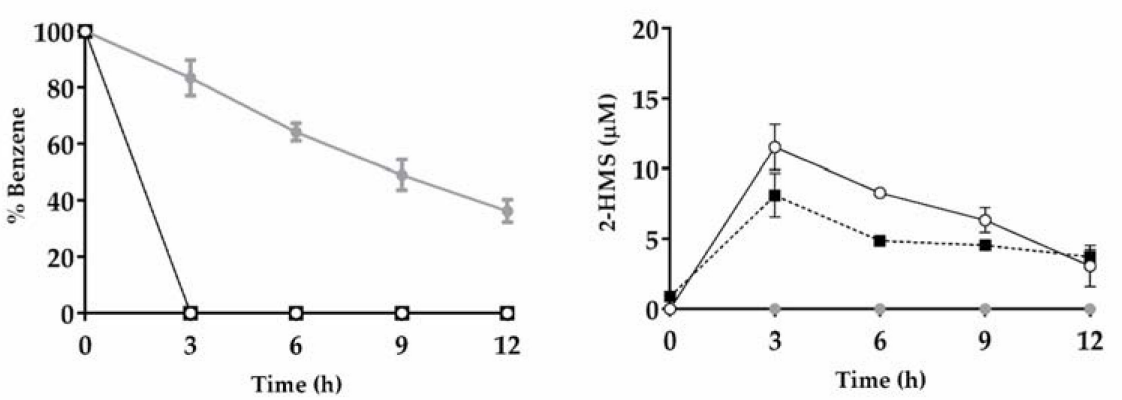

Figure 7. Effects of cadmium on benzene degradation ( $5 \mathrm{mM})$ and 2-HMS formation by C. metallidurans $\mathrm{CH} 34$ and P. putida $\mathrm{F} 1$. Effects of $\mathrm{CdCl}_{2}(200 \mu \mathrm{M})$ on (A) C. metallidurans $\mathrm{CH} 34$ and (B) P. putida $\mathrm{F} 1$. Each point is an average \pm SDs of results from three independent resting cells assays. 


\section{Discussion}

\subsection{Aromatic Catabolic Reconstruction of C. metallidurans $\mathrm{CH} 34$}

In this study, we reported a wide variety of aromatic compounds that can be used as carbon source by $\mathrm{C}$. metallidurans $\mathrm{CH} 34$, and the aromatic catabolic pathways including the routes to degrade BTEX, chlorobenzoates, and lignin-derived compounds were inferred from genomic studies. We also reported new metabolic insights to describe the benzene catabolic pathways observing intermediates at different growth stages and by functional expression of key genes. Finally, we studied the effects of the presence of heavy metals on benzene degradation since the capabilities of strain $\mathrm{CH} 34$ to degrade aromatic compounds such as benzene in the presence or absence of toxic heavy metals have been scarcely reported in the wild-type strain CH34 [44]. Springael et al. transferred the plasmid pSS50, which is involved in polychlorobiphenyl (PCB) degradation, into strain CH34 to study the effect of nickel and zinc ions on PCB degradation by the transconjugant strain AE707, overlooking the innate catabolic potential of strain $\mathrm{CH} 34$ [26,45]. Aromatic degradation by Cupriavidus strains has been described, but only three genomes have been sequenced and analyzed to prospect their overall aromatic degradation capabilities: the chloroaromatic degrader C. pinatubonensis JMP134, the lignin degrader C. basilensis B-8, and the 3-CBA degrader $C$. necator NH9 $[27,67,68]$. Of note are the harboring of $C 1$ and $C 2$ genes by $C$. metallidurans $\mathrm{CH} 34$, which confers a similar catabolic versatility to strain JMP134, a well-known aromatic degrader model [69], including multiple central pathways for aromatic degradation (the protocatechuate and the catechol $\beta$-ketoadipate pathways; the meta-cleavage catechol pathway; the HQ pathway; the homogentisate pathway; the 3-hydroxyanthranilate pathway; and the hybrid aerobic pathways 2-aminobenzoyl-CoA, phenylacetyl-CoA, and benzoyl-CoA), three BMMs, and genes encoding benzoate and lignin-derived degradation enzymes. Morever, these results showed the ability of strain CH34 to grow on 3-CBA and 3,5-CBA despite the absence of canonical chlorocatechol pathways ( $t f d$ and $c l c$ genes). Following these results, previous studies reported that $\mathrm{C} 12 \mathrm{O}$ of strain $\mathrm{CH} 34$ possesses a unique spectrum to cleave substituted-catechols in ortho position, including tetrachlorocatechol, 4-fluorocatechol, 4-methylcatechol, and 3-methylcatechol [70,71]. Even though specific pathways for chloro-substituted aromatics were not identified in the CH34 genome, the benzoate 1,2-dioxygenase BenABCD may perform the dioxygenase activation with a lower affinity to convert 3-CBA and 3,5-CBA into chlorocatechols, which has been reported during degradation of 3-CBA by C. pinatubonensis JMP134 [72]. Transcriptome profiling of C. necator NH9 cells grown on 3-CBA compared to benzoate supports the hypothesis that 3-CBA and benzoate are degraded by a common pathway [68].

In the present study, we also observed that $C$. metallidurans $\mathrm{CH} 34$ grew on benzene, toluene, ethylbenzene, and xylenes. In addition, $\mathrm{CH} 34$ cells are also able to grow on $p$ cymene, BA, 3-CBA, 3,5-CBA, salicylate, 3-HBA, 4-HBA, pABA, PA, 3-HPA, 4-HPA, vanillin, and cinnamate. These results support the corresponding catabolic pathways identified by genomic analyses (Table 1). Although strain $\mathrm{CH} 34$ grew on salicylate, $p$-cymene, 3-HBA, 3-HPA, 4-HPA, benzamide, pABA, and cinnamate, ortholog genes for their previously described catabolic pathways were not found in the $\mathrm{CH} 34$ genome, suggesting the presence of still undescribed catabolic pathways in the Cupriavidus genus. The absence of degradative canonical pathways of phenylpropanoids (cinnamate, phenylpropionates) and 4-HPA in Cupriavidus strains B-8, NH9, and JMP134, despite their growth on these compounds $[27,31,67]$, indicate that members of the Cupriavidus genus may degrade them via novel catabolic pathways. Cytochrome P450 OhpA is a self-sufficient cytochrome involved in the transformation of 2-HPA into homogentisate, which was described recently in C. pinatubonensis JMP134 [73], being also present in the genome of strain CH34 (RMET_RS25305), evidencing the need for further characterization of novel enzymatic activities in the Cupriavidus genus. 


\subsection{BMMs in C. metallidurans $\mathrm{CH} 34$}

The presence of more than one BMM observed in C. metallidurans strain $\mathrm{CH} 34$ is rare in bacteria, with its co-expression potentially leading to the formation of a complex modularity, generating new substrate specificity and providing optimized metabolic capabilities $[40,48,74]$. The first $\mathrm{BMM}$ of strain $\mathrm{CH} 34$ was constituted by T2MO (encoded by the tom $A 012345$ gene cluster), which possesses a high similarity in amino acid sequence and gene organization to the B. vietnamiensis G4 T2MO subunits (Figure 2 and Table S1), suggesting a regiospecific hydroxylation of toluene into $o$-cresol and, subsequently, an oxidation into 3-methylcatechol [75-77]. In addition, T2MO catalyzes the oxidation of dichloroethylenes, chloroform, 1,4-dioxane, aliphatic ethers, and diethyl sulphide $[76,78]$ and enables the formation of epoxides from a variety of alkene substrates [79]. The second $\mathrm{CH} 34 \mathrm{BMM}$ is the TMO encoded by the tmo $A B C D E F$ gene cluster, which belongs to the group II BMMs. The products of these genes are similar to the corresponding subunits of the BMMs TbcABCDEF (C. pinatubonensis JMP134 and B. cepacia JS150) and TmoABCEDF ( $P$. mendocina KR1) (Figure 2). All these BMMs have different substrate specificities, enabling the oxidation of toluene and other BTEX compounds $[54,80]$. For example, T4MO of strain KR1 oxidizes toluene into 4-methylcatechol and catalyzes the formation of epoxides [79], as well as the oxidation of phenols and methylphenols into catechol [75]. An outstanding broad substrate group II BMM is the toluene $o$-xylene monooxygenase (ToMO) of P. stutzeri OX1, which oxidizes $o$-xylene, $m$-xylene, $p$-xylene, toluene, benzene, ethylbenzene, styrene, naphthalene, and tetrachloroethylene [74]. The characterization of the hydroxylation capabilities of $\mathrm{CH} 34 \mathrm{TMO}$ should be performed due to their potential broad substrate specificity and the classification of the $\mathrm{CH} 34 \mathrm{TmoE}$ subunit as a singleton in the phylogenetic analysis of $\gamma$-hydroxylase subunit of the group II BMMs. C. metallidurans $\mathrm{CH} 34$ genome encodes a third BMM, a PH that is encoded by the phyZABCDE gene cluster. This enzyme is also present in C. pinatubonensis JMP134 and transforms benzene into phenol, and then into catechol (Figure 5). In accordance, the phyZABCDE gene cluster is located upstream of the catA1 gene, which encodes a catechol 1,2-dioxygenase (C12O) (Figure 2, Table S3) [39]. The phy-catA1 gene cluster might be controlled by PoxR, a phenol-sensitive XylR/NtrC-like transcriptional activator (Table S3). Furthermore, an additional $\mathrm{C} 12 \mathrm{O}$ is encoded on the C2 (RMET_RS25045) and belongs to the benzoate catabolic ben-cat gene cluster [28]. Multiple BMMs were encountered in other Burkholderiales degraders (B. cenocepacia JS150 and C. pinatubonensis JMP134), which could account for their exceptionally versatile catabolic capabilities [28].

\subsection{Functionality of CH34 BMMs Associated with the Degradation of Benzene}

In this study, the functionality of $\mathrm{CH} 34$ BMMs associated with the degradation of benzene was reported for the first time. Transcriptional analyses and kinetics of the metabolic intermediates indicated that $\mathrm{CH} 34 \mathrm{BMM}$ activities depend on the growth phase. Phenol accumulation during $\mathrm{CH} 34$ growth on benzene was observed (Figure 3B). The results of this study suggest that one or more BMMs could be activated simultaneously during the process, thereby indicating the occurrence of a complex degrading module to generate a catabolic strategy. Interestingly, activation of diverse BMMs has been proposed in C. pinatubonensis JMP134, R. pickettii PKO1, and B. cenocepacia JS150 [48,54,80]. RT-qPCR revealed the successive use of two transcription profiles according to the growth phase. At early exponential phase, two BMM-encoding gene clusters (tom $A 012345$ and tmo $A B C D E F$ ), and tomB, tom $C$, and tom $D$ genes forming the $\mathrm{C} 23 \mathrm{O}$ pathway that all belong to the CMGI-2 catabolic gene cluster (Figure 4) were induced. In contrast, at late exponential phase, the phyZABCDE gene cluster encoding the $\mathrm{PH}$, and the cat $A 1$ and cat $A 2$ genes that compose the $\mathrm{C} 12 \mathrm{O}$ pathway were upregulated. This transcription profile associated with the late exponential growth phase during benzene catabolism is in agreement with the downstream location of a rpoS promoter and the reported inhibition of $\mathrm{C} 12 \mathrm{O}$ activity in the presence of phenol [54]. Therefore, these results suggest an induction of the $\mathrm{C} 12 \mathrm{O}$ pathway only at late growth phase on benzene at ultimately lower phenol concentrations (Figure 7). 
Transcription analyses and metabolic intermediate detection suggest that meta-cleavage of catechol is catalyzed by a C23O (TomB) at early stages of growth, whereas ortho-cleavage, catalyzed by a $\mathrm{C} 12 \mathrm{O}$ (CatA1, CatA2) at late stages of growth, is driven by starvation and the general stress transcriptional factor RpoS. Although versatile predominance between the $\mathrm{C} 12 \mathrm{O}$ or $\mathrm{C} 23 \mathrm{O}$ degradation pathways has been previously reported as dependent of substrate and concentration [81,82], more analyses should be performed to determine to which extent each $\mathrm{CH} 34$ catabolic pathway is involved in benzene degradation.

\subsection{Effect of Benzene on Bacterial Cadmium MICs}

Cadmium MICs of C. metallidurans CH34 and P. putida F1 grown on benzene were significantly lower compared to MICs of succinate-growing bacteria. However, cadmium showed a higher impact on strain F1. These results are in agreement with the heavy metal resistance niche specialization of the $\mathrm{CH} 34$ strain, reflexed on its horizontal acquisition and duplication of genes that encode cadmium efflux systems [39,83,84], some of which are represented as homologous genes in the genome of strain F1, although to a significant lower extent [85].

Previously, we have reported in strain CH34 that Cd (II) induces genes encoding the cadmium efflux system CadA and the mercury reductase MerA that are involved in heavy metal response [41]. In addition, cadmium decreases the second messenger c-di-GMP, induces a metal regulated phosphodiesterase, and inhibits biofilm formation [41]. Aromatic hydrocarbons may increase membrane fluidity, causing non-specific permeabilization and membrane protein disruption [86,87], which may affect the cation uptake and explain the reduced MIC values. The occurrence of futile cycles during cadmium detoxification, but not in mercury detoxification systems, has been reported due to the volatile nature of the mercury detoxification product [88]. Therefore, a faulty efflux system for Cd (II) may originate from benzene exposure in both $\mathrm{CH} 34$ and F1 strains. Cd (II) induces oxidative stress in bacteria [88]. An increase in reactive oxygen species by cadmium can lead to protein carbonylation, lipoperoxidation, and oxidative damage to DNA, which may act in synergy with benzene-induced membrane disruption, strongly reducing cell viability [89].

\subsection{Effects of Mercury and Cadmium on Benzene Degradation}

In the present study, the effects of mercury and cadmium on benzene degradation by C. metallidurans $\mathrm{CH} 34$ and the model benzene/toluene-degrader P. putida F1 were studied and compared. In the absence of heavy metals, P. putida strain F1 showed a higher benzene degradation rate than $C$. metallidurans $\mathrm{CH} 34$. Benzene transformation into catechol via dioxygenases is achieved using a single oxygen molecule, whereas monooxygenase-mediated activation converts benzene to catechol in two hydroxylation steps, with the accumulation of the toxic metabolic intermediate phenol [54]. While mercury and cadmium concentrations used in the benzene degradation assays by a resting cell approach were not equitoxic in comparison with respective MICs of C. metallidurans $\mathrm{CH} 34$ or P. putida F1, these concentrations corresponded to minimal heavy metal concentrations that showed observable effects on benzene degradation in both strains. Heavy metal effect on benzene catabolism in both strains could also be attributed to a general stress response, affecting other enzymatic systems that could indirectly influence the degradation rate of each compound. Nevertheless, the concentrations evaluated and their effects are in accordance with the differences within both cytoplasmic detoxification systems aforementioned in Section 4.4.

In the presence of mercury, C. metallidurans $\mathrm{CH} 34$ showed higher MICs during growth on benzene and on succinate than P. putida strain F1. Strain CH34 possesses a moderate mercury resistance, whereas P. putida F1 is a mercury-sensitive strain [35,40,41,90], which is in accordance with the effect of mercury exposure on benzene degradation assays observed. Notably, C. metallidurans CH34 showed a slightly higher degradation rate of benzene in the presence of mercury $(32.5 \mu \mathrm{M}$; Figure $6 \mathrm{~A})$ than in the absence of this heavy metal; in contrast, P. putida F1 was unable to degrade benzene in the presence of mercury. The increased $\mathrm{CH} 34$ benzene degradation in the presence of mercury is noteworthy since the 
reported detrimental effect of mercury $(36,180$, and $360 \mu \mathrm{M})$ on the catabolism of aromatic compounds in soil microbiota [14]. Although the modest increase in the benzene degradation rate was observed by strain $\mathrm{CH} 34,2-\mathrm{HMS}$ production rate was lower than the unexposed condition after the $6 \mathrm{~h}$, suggesting dissimilar effects for the upper or lower benzene catabolic pathway. Interestingly, the induction by arsenic of the $m$-xylene degradation genes in P. putida $\mathrm{mt} 2$ has been described [91]; therefore, the induction of some catabolic genes by some metals might not be discarded. Future studies should investigate the transcriptional regulation and possible co-activation of the benzene degradation pathway and the mer genes in C. metallidurans $\mathrm{CH} 34$.

Strains $\mathrm{CH} 34$ and F1 were able to degrade benzene in the presence of cadmium. Cd (II) $(200 \mu \mathrm{M})$ slightly decreased the benzene degradation by $\mathrm{C}$. metallidurans $\mathrm{CH} 34$ during the first $6 \mathrm{~h}$ (Figure 7A), but no inhibition on degradation was observed after longer incubation (Figures 7 and S1). The impairment of phenol production during the short incubation time may have been caused by the destabilization of T2MO and TMO (2Fe-2S) clusters by cadmium, which has been reported for copper and zinc [92-94]. The partial decrease in 2-HMS production caused by cadmium could be explained by the mixed nature of C. metallidurans $\mathrm{CH} 34$ catabolic pathway, in which the cytoplasmic presence of Cd (II) may favor $\mathrm{C} 12 \mathrm{O}$ activity instead of $\mathrm{C} 23 \mathrm{O}$. The location of the cat $A 1$ gene downstream of a RpoS promoter is in accordance with an induction of its expression under cadmium stress [95-97]. In addition, cadmium impairs $\mathrm{C} 23 \mathrm{O}$ activity in Stenotrophomonas maltophilia $\mathrm{KB} 2$ and Variovorax sp. $12 \mathrm{~S}$ while increasing in vitro $\mathrm{C} 12 \mathrm{O}$ activity by up to $270 \%[98,99]$. It has been reported that cadmium binds to $\mathrm{C} 23 \mathrm{O}$ extradiol aromatic ring cleaving dioxygenases, replacing $\mathrm{Fe}$ (II) in its catalytic binding site [100], but not to the $\mathrm{C} 12 \mathrm{O}$ dioxygenase active site, which contains Fe (III) [71].

On the other hand, P. putida strain F1 achieved a similar benzene degradation rate in the presence or absence of cadmium, suggesting that the dioxygenase-mediated catabolism is not affected by cadmium. In accordance, the toluene dioxygenase active site containing Fe (III) showed non-susceptibility to divalent cation ligand substitution [101].

\section{Conclusions}

This study showed that $\mathrm{C}$. metallidurans $\mathrm{CH} 34$ possesses a wide aromatic catabolic versatility and is able to grow on a broad range of monoaromatic compounds including BTEX compounds, chlorobenzoates, and lignin-derived aromatics. CH34 benzene degradation occurs by the activation of the aromatic ring through three BMMs and a central mixed route composed by $\mathrm{C} 12 \mathrm{O}$ and $\mathrm{C} 23 \mathrm{O}$ catechol dioxygenases that are differentially regulated at early and late exponential growth phases. Notably, strain $\mathrm{CH} 34$ degraded benzene in the presence of the toxic heavy metals mercury and cadmium. The presence of mercury $(32.5 \mu \mathrm{M})$ slightly favored benzene degradation in C. metallidurans $\mathrm{CH} 34$; however, it inhibited benzene degradation in P. putida F1. Cadmium $(200 \mu \mathrm{M})$ decreased benzene degradation by strain $\mathrm{CH} 34$ during short incubation $(6 \mathrm{~h})$ but not after longer time periods, whereas P. putida F1 degradation was not affected. These results indicate that $C$. metallidurans $\mathrm{CH} 34$ is an attractive biocatalyst for the bioremediation of BTEX in sites polluted with aromatic compounds and heavy metals such as mercury and cadmium.

Supplementary Materials: The following supporting information can be downloaded at https: / / www.mdpi.com/article/10.3390/microorganisms10020484/s1, Figure S1: Effects of cadmium and mercury on phenol production in C. metallidurans $\mathrm{CH} 34$ during resting cell assays. Table S1: Bacterial multicomponent monooxygenase operon information of Cupriavidus metallidurans strain CH34 and other Proteobacteria. Table S2: Primer sets designed and used in this study. Table S3: Predicted aromatic central pathways in C. metallidurans CH34. Table S4: Predicted aromatic peripheral pathways in C. metallidurans CH34. Table S5: Statistic analysis of mercury and cadmium effects on benzene degradation and intermediate production by C. metallidurans $\mathrm{CH} 34$ and P. putida F1. 
Author Contributions: P.A.-G., R.E.D., F.A.M., F.C., L.A.R. and M.S. conceived and designed the experiments. P.A.-G., R.E.D., F.A.M. and F.C. performed the experiments. P.A.-G., R.E.D., F.A.M., F.C., L.A.R. and M.S. analyzed the data. M.S. and L.A.R. contributed reagents, materials, and analysis tools. P.A.-G., R.E.D., F.A.M., L.A.R. and M.S. prepared figures and/or tables. P.A.-G., R.E.D., F.A.M., F.C., L.A.R. and M.S. authored or reviewed drafts of the manuscript. All authors have read and agreed to the published version of the manuscript.

Funding: This research was funded by ANID PIA Ring Genomics and Applied Microbiology for Bioremediation and Bioproducts (GAMBIO) ACT172128 Chile (M.S., P.A.-G., R.E.D.), as well as Fondecyt 11130117 (L.A.R.), Fondecyt 1200756 (M.S., R.E.D.), and USM PI_M_2020_43 (R.E.D., M.S.) grants.

Institutional Review Board Statement: Not applicable.

Informed Consent Statement: Not applicable.

Data Availability Statement: Not applicable.

Acknowledgments: The authors thank Danilo Pérez-Pantoja and Raúl Donoso for providing strain P. putida F1, vanillin, and L-phenylalanine. The authors acknowledge Vicente Saona-Urmeneta and Carlos Buil-Aranda for the visualization of BMM gene clusters.

Conflicts of Interest: The authors declare no conflict of interest. The funders had no role in the design of the study; in the collection, analyses, or interpretation of data; in the writing of the manuscript; or in the decision to publish the results.

\section{References}

1. Fuchs, G.; Boll, M.; Heider, J. Microbial degradation of aromatic compounds- From one strategy to four. Nat. Rev. Microbiol. 2011, 9, 803-816. [CrossRef] [PubMed]

2. Fuentes, S.; Méndez, V.; Aguila, P.; Seeger, M. Bioremediation of petroleum hydrocarbons: Catabolic genes, microbial communities, and applications. App. Microbiol. Biotech. 2014, 98, 4781-4794. [CrossRef] [PubMed]

3. Liu, S.H.; Lai, C.Y.; Ye, J.W.; Lin, C.W. Increasing removal of benzene from groundwater using stacked tubular air-cathode microbial fuel cells. J. Clean. Prod. 2018, 194, 78-84. [CrossRef]

4. van der Perk, M. Soil and Water Contamination, 2nd ed.; Organic Pollutants; CRC Press: Leiden, The Netherland, $2014 ;$ p. 167.

5. Nojiri, H.; Tsuda, M.; Kamagata, Y.; Fukuda, M. Biodegradative Bacteria: How Bacteria Degrade, Survive, Adapt, and Evolve; Springer: Tokyo, Japan, 2014; p. 228. [CrossRef]

6. Sandrin, T.R.; Maier, R.M.M. Impact of metals on the biodegradation of organic pollutants. Health Perspect. 2003, $111,1093-1101$. [CrossRef]

7. Sprocati, A.R.; Alisi, C.; Tasso, F.; Marconi, P.; Sciullo, A.; Pinto, V.; Chiavarini, S.; Ubaldi, C.; Cremisini, C. Bioremediation of diesel oil in a co-contaminated soil by bioaugmentation with a microbial formula tailored with native strains selected for heavy metals resistance. Process Biochem. 2012, 47, 1649-1655. [CrossRef]

8. Nies, D. The biological chemistry of the transition metal transportome of: Cupriavidus metallidurans. Metallomics 2016, 8, 481-507. [CrossRef]

9. Méndez, V.; Fuentes, S.; Morgante, V.; Hernández, M.; González, M.; Moore, E.; Seeger, M. Novel hydrocarbonoclastic metaltolerant Acinetobacter and Pseudomonas strains from Aconcagua river oil-polluted soil. J. Soil Sci. Plant Nutr. 2017, 17, 1074-1087. [CrossRef]

10. Liu, X.X.; Hu, X.; Cao, Y.; Pang, W.J.; Huang, J.Y.; Guo, P.; Huang, L. Biodegradation of phenanthrene and heavy metal removal by acid-tolerant Burkholderia fungorum FM-2. Front. Microbiol. 2019, 10, 408. [CrossRef]

11. Bravo, G.; Vega-Celedón, P.; Gentina, J.C.; Seeger, M. Bioremediation by Cupriavidus metallidurans strain MSR33 of mercury-polluted agricultural soil in a rotary drum bioreactor and its effects on nitrogen cycle microorganisms. Microorganisms 2020, 8, 1952. [CrossRef]

12. Gran-Scheuch, A.; Ramos-Zuñiga, J.; Fuentes, E.; Bravo, D.; Pérez-Donoso, J.M. Effect of co-contamination by PAHs and heavy metals on bacterial communities of diesel contaminated soils of South Shetland Islands, Antarctica. Microorganisms 2020, 8, 1749. [CrossRef]

13. Rizzuti, A.M.; Cohen, A.D.; Stack, E.M. Effects of irradiating peats on their ability to extract BTEX and cadmium from contaminated water. J. Environ. Sci. Health A 1996, 31, 1917-1949. [CrossRef]

14. Baldrian, P.; in der Wiesche, C.; Jiří, G.; Nerud, F.; Zadražil, F. Influence of cadmium and mercury on activities of ligninolytic enzymes and degradation of polycyclic aromatic hydrocarbons by Pleurotus ostreatus in soil. Appl. Environ. Microbiol. 2000, 66, 2471-2478. [CrossRef] [PubMed]

15. Kavamura, V.N.; Esposito, E. Biotechnological strategies applied to the decontamination of soils polluted with heavy metals. Biotechnol. Adv. 2010, 28, 61-69. [CrossRef] [PubMed]

16. Ekperusi, O.A.; Aigbodion, I.F. Bioremediation of heavy metals and petroleum hydrocarbons in diesel contaminated soil with the earthworm: Eudrilus eugeniae. SpringerPlus 2015, 4, 1-13. [CrossRef] [PubMed] 
17. Joseph, P. Mechanisms of cadmium carcinogenesis. Toxicol. Appl. Pharmacol. 2009, 238, 272-279. [CrossRef]

18. Begg, S.L.; Eijkelkamp, B.A.; Luo, Z.; Couñago, R.M.; Morey, J.R.; Maher, M.J.; Ong, C.L.Y.; McEwan, A.G.; Kobe, B.; O’Mara, M.L.; et al. Dysregulation of transition metal ion homeostasis is the molecular basis for cadmium toxicity in Streptococcus pneumoniae. Nat. Commun. 2015, 6, 1-11. [CrossRef]

19. Kovarik, W. Ethyl-leaded gasoline: How a classic occupational disease became an international public health disaster. Int. J. Occup. Environ. Health 2005, 11, 384-397. [CrossRef]

20. Kristensen, A.K.B.; Thomsen, J.F.; Mikkelsen, S. A review of mercury exposure among artisanal small-scale gold miners in developing countries. Int. Arch. Occup. Environ. Health 2014, 87, 579-590. [CrossRef]

21. Bravo, G.; Vega-Celedón, P.; Gentina, J.C.; Seeger, M. Effects of mercury II on Cupriavidus metallidurans strain MSR33 during mercury bioremediation under aerobic and anaerobic conditions. Processes 2020, 8, 893. [CrossRef]

22. Amor, L.; Kennes, C.; Veiga, M.C. Kinetics of inhibition in the biodegradation of monoaromatic hydrocarbons in presence of heavy metals. Bioresour. Technol. 2001, 78, 181-185. [CrossRef]

23. Harrison, J.J.; Ceri, H.; Turner, R.J. Multimetal resistance and tolerance in microbial biofilms. Nat. Rev. Microbiol. 2007, 5, 928-938. [CrossRef] [PubMed]

24. Boyd, E.S.; Barkay, T. The mercury resistance operon: From an origin in a geothermal environment to an efficient detoxification machine. Front. Microbiol. 2012, 3, 1-13. [CrossRef] [PubMed]

25. Montero-Silva, F.; Durán, N.; Seeger, M. Synthesis of extracellular gold nanoparticles using Cupriavidus metallidurans CH34 cells. IET Nanobiotechnol. 2018, 12, 40-46. [CrossRef]

26. Springael, D.; Diels, L.; Hooyberghs, L.; Kreps, S.; Mergeay, M. Construction and characterization of heavy metal-resistant haloaromatic-degrading Alcaligenes eutrophus strains. Appl. Environ. Microbiol. 1993, 59, 334-339. [CrossRef]

27. Pérez-Pantoja, D.; De la Iglesia, R.; Pieper, D.H.; González, B. Metabolic reconstruction of aromatic compounds degradation from the genome of the amazing pollutant-degrading bacterium Cupriavidus necator JMP134. FEMS Microbiol. Rev. 2008, 32, 736-794. [CrossRef]

28. Pérez-Pantoja, D.; Donoso, R.; Agulló, L.; Córdova, M.; Seeger, M.; Pieper, D.H.; González, B. Genomic analysis of the potential for aromatic compounds biodegradation in Burkholderiales. Environ. Microbiol. 2012, 14, 1091-1117. [CrossRef]

29. Fang, L.C.; Chen, Y.F.; Wang, D.S.; Sun, L.N.; Tang, X.Y.; Hua, R.M. Complete genome sequence of a novel chlorpyrifos degrading bacterium, Cupriavidus nantongensis X1. J. Biotechnol. 2016, 227, 1-2. [CrossRef]

30. Van Houdt, R.; Provoost, A.; Van Assche, A.; Leys, N.; Lievens, B.; Mijnendonckx, K.; Monsieurs, P. Cupriavidus metallidurans strains with different mobilomes and from distinct environments have comparable phenomes. Genes 2018, 9, 507. [CrossRef]

31. Moriuchi, R.; Dohra, H.; Kanesaki, Y.; Ogawa, N. Complete genome sequence of 3-chlorobenzoate-degrading bacterium Cupriavidus necator NH9 and reclassification of the strains of the genera Cupriavidus and Ralstonia based on phylogenetic and whole-genome sequence analyses. Front. Microbiol. 2019, 10, 133. [CrossRef]

32. Alvarez-Santullano, N.; Villegas, P.; Mardones, M.S.; Durán, R.E.; Donoso, R.; González, A.; Sanhueza, C.; Navia, R.; Acevedo, F.; Pérez-Pantoja, D.; et al. Genome-wide metabolic reconstruction of the synthesis of polyhydroxyalkanoates from sugars and fatty acids by Burkholderia sensu lato species. Microorganisms 2021, 9, 1290. [CrossRef]

33. Suenaga, H.; Yamazoe, A.; Hosoyama, A.; Kimura, N.; Hirose, J.; Watanabe, T.; Fujihara, H.; Futagami, T.; Goto, M.; Furukawa, K. Draft genome sequence of the polychlorinated biphenyl-degrading bacterium Cupriavidus basilensis KF708 (NBRC 110671) isolated from biphenyl-contaminated soil. Genome Announc. 2015, 3, e00143-15. [CrossRef]

34. Seeger, M.; Saavedra, J.M.; Acevedo, F. Recombinant PCB-degrading bacterium, product for bioremediation and method of application. U.S. Patent 7,989,194 B2, 2 August 2011.

35. Rojas, L.A.; Yáñez, C.; González, M.; Lobos, S.; Smalla, K.; Seeger, M. Characterization of the metabolically modified heavy metal-resistant Cupriavidus metallidurans strain MSR33 generated for mercury bioremediation. PLoS ONE 2011, 6, e0017555. [CrossRef] [PubMed]

36. Espinoza-Tofalos, A.; Daghio, M.; González, M.; Papacchini, M.; Franzetti, A.; Seeger, M. Toluene degradation by Cupriavidus metallidurans $\mathrm{CH} 34$ in nitrate-reducing conditions and in bioelectrochemical systems. FEMS Microbiol. Lett. 2018, 365 , fny119. [CrossRef]

37. Monchy, S.; Benotmane, M.A.; Janssen, P.; Vallaeys, T.; Taghavi, S.; van der Lelie, D.; Mergeay, M. Plasmids pMOL28 and pMOL30 of Cupriavidus metallidurans are specialized in the maximal viable response to heavy metals. J. Bacteriol. 2007, 189, 7417-7425. [CrossRef] [PubMed]

38. Janssen, P.J.; Van Houd, T.R.; Moors, H.; Monsieurs, P.; Morin, N.; Michaux, A.; Benotmane, R.; Leys, N.; Vallaeys, T.; Lapidus, A.; et al. The complete genome sequence of Cupriavidus metallidurans strain $\mathrm{CH} 34$, a master survivalist in harsh and anthropogenic environments. PLoS ONE 2010, 5, e10433. [CrossRef]

39. Millacura, F.A.; Janssen, P.J.; Monsieurs, P.; Janssen, A.; Provoost, A.; Van Houdt, R.; Rojas, L.A. Unintentional genomic changes endow Cupriavidus metallidurans with an augmented heavy-metal resistance. Genes 2018, 9, 551. [CrossRef] [PubMed]

40. Alviz-Gazitua, P.; Fuentes-Alburquenque, S.; Rojas, L.A.; Turner, R.J.; Guiliani, N.; Seeger, M. The response of Cupriavidus metallidurans $\mathrm{CH} 34$ to cadmium involves inhibition of the initiation of biofilm formation, decrease in intracellular c-di-GMP levels, and a novel metal regulated phosphodiesterase. Front. Microbiol. 2019, 10, 1-17. [CrossRef] 
41. Seeger, M.; Rojas, L.; González, M.; Yáñez, C. Recombinant Bacterium Capable of Removing Mercury (II) Species, Cadmium (II) and Copper (II) in Presence of other Heavy Metals from Polluted Sites, Product for the Bioremediation, Process of Obtaining the Product and Method of Bioremediation. U.S. Patent 8,846,376B2, 30 September 2014.

42. Mergeay, M.; Nies, D.; Schlegel, H.G.; Gerits, J.; Charles, P.; Van Gijsegem, F. Alcaligenes eutrophus CH34 is a facultative chemolithotroph with plasmid-bound resistance to heavy metals. J. Bacteriol. 1985, 162, 328-334. [CrossRef]

43. Rosier, C.; Leys, N.; Henoumont, C.; Mergeay, M.; Wattiez, R. Purification and characterization of the acetone carboxylase of Cupriavidus metallidurans Strain CH34. Appl. Environ. Microbiol. 2012, 78, 4516-4518. [CrossRef]

44. Van Houdt, R.; Monsieurs, P.; Mijnendonckx, K.; Provoost, A.; Janssen, A.; Mergeay, M.; Leys, N. Variation in genomic islands contribute to genome plasticity in Cupriavidus metallidurans. BMC Genom. 2012, 13, 111. [CrossRef]

45. Springael, D.; Diels, L.; Mergeay, M. Transfer and expression of PCB-degradative genes into heavy metal resistant Alcaligenes eutrophus strains. Biodegradation 1994, 5, 343-357. [CrossRef] [PubMed]

46. David, C.; Daro, A.; Szalai, E.; Atarhouch, T.; Mergeay, M. Formation of polymeric pigments in the presence of bacteria and comparison with chemical oxidative coupling-II. Catabolism of tyrosine and hydroxyphenylacetic acid by Alcaligenes eutrophus CH34 and mutants. Eur. Polym. J. 1996, 32, 669-679. [CrossRef]

47. Van Houdt, R.; Monchy, S.; Leys, N.; Mergeay, M. New mobile genetic elements in Cupriavidus metallidurans CH34, their possible roles and occurrence in other bacteria. Antonie Leeuwenhoek 2009, 96, 205-226. [CrossRef]

48. Notomista, E.; Lahm, A.; Di Donato, A.; Tramontano, A. Evolution of bacterial and archaeal multicomponent monooxygenases. J. Mol. Evol. 2003, 56, 435-445. [CrossRef]

49. Reardon, K.F.; Mosteller, D.C.; Bull Rogers, J.D. Biodegradation kinetics of benzene, toluene, and phenol as single and mixed substrates for Pseudomonas putida F1. Biotechnol. Bioeng. 2000, 69, 385-400. [CrossRef]

50. Durán, R.E.; Méndez, V.; Rodriguez-Castro, L.; Barra-Sanhueza, B.; Salvà-Serra, F.; Moore, E.R.B.; Castro-Nallar, E.; Seeger, M. Genomic and physiological traits of the marine bacterium Alcaligenes aquatilis QD168 isolated from Quintero Bay, Central Chile, reveal a robust adaptive response to environmental stressors. Front. Microbiol. 2019, 10, 528. [CrossRef] [PubMed]

51. Ng, L.C.; Shingle, V.; Sze, C.C.; Poh, C.L. Cloning and sequences of the first eight genes of the chromosomally encoded (methyl) phenol degradation pathway from Pseudomonas putida P35X. Gene 1994, 151, 29-36. [CrossRef]

52. Reardon, K.F.; Mosteller, D.C.; Rogers Bull, J.D.; DuTeau, N.M.; Kim, K.H. Biodegradation kinetics of aromatic hydrocarbon mixtures by pure and mixed bacterial cultures. Environ. Health Persp. 2002, 110, 1005-1101. [CrossRef]

53. Sandhu, A.; Halverson, L.J.; Beattie, G.A. Bacterial degradation of airborne phenol in the phyllosphere. Environ. Microbiol. 2007, 9, 383-392. [CrossRef]

54. Parales, R.E.; Parales, J.V.; Pelletier, D.A.; Ditty, J.L. Chapter 1 Diversity of microbial toluene degradation pathways. Adv. Appl. Microbiol. 2008, 64, 1-73. [CrossRef]

55. Cai, S.; Chen, L.W.; Ai, Y.C.; Qiu, J.G.; Wang, C.H.; Shi, C.; He, J.; Cai, T.M. Degradation of diphenyl ether in Sphingobium phenoxybenzoativorans SC_3 is initiated by a novel ring cleavage dioxygenase. Appl. Environ. Microbiol. 2017, 83, e00104-17. [CrossRef] [PubMed]

56. Arai, H.; Ishii, M. Draft genome sequence of Comamonas testosteroni TA441, a bacterium that has a cryptic phenol degradation gene cluster. Microbiol. Resour. Announc. 2019, 8, e00946-19. [CrossRef]

57. Katoh, K.; Misawa, K.; Kuma, K.I.; Miyata, T. MAFFT: A novel method for rapid multiple sequence alignment based on fast Fourier transform. Nucleic Acids Res. 2002, 30, 3059-3066. [CrossRef] [PubMed]

58. Larsson, A. AliView: A fast and lightweight alignment viewer and editor for large datasets. Bioinformatics 2014, 30, 3276-3278. [CrossRef] [PubMed]

59. Ronquist, F.; Teslenko, M.; Van Der Mark, P.; Ayres, D.L.; Darling, A.; Höhna, S.; Larget, B.; Liu, L.; Suchard, M.A.; Huelsenbeck, J.P. Mrbayes 3.2: Efficient bayesian phylogenetic inference and model choice across a large model space. Syst. Biol. 2012, 61, 539-542. [CrossRef] [PubMed]

60. Taylor, S.; Wakem, M.; Dijkman, G.; Alsarraj, M.; Nguyen, M. A practical approach to RT728 qPCR-Publishing data that conform to the MIQE guidelines. Methods 2010, 50, 729. [CrossRef]

61. Pfaffl, M.W.; Tichopad, A.; Prgomet, C.; Neuvians, T.P. Determination of stable housekeeping genes, differentially regulated target genes and sample integrity: BestKeeper-Excel-based tool using pair-wise correlation. Biotechnol. Lett. 2004, $26,509-515$. [CrossRef]

62. Pfaffl, M.W. A new mathematical model for relative quantification in real-time RT-PCR. Nucleic Acids Res. 2001, 29, e45. [CrossRef]

63. Sala-Trepat, J.M.; Evans, W.C. The meta cleavage of catechol by Azotobacter species. 4-Oxalocrotonate pathway. Eur. J. Biochem. 1971, 20, 400-413. [CrossRef]

64. Hearn, E.M.; Patel, D.R.; Van Den Berg, B. Outer-membrane transport of aromatic hydrocarbons as a first step in biodegradation. Proc. Natl. Acad. Sci. USA 2008, 105, 8601-8606. [CrossRef]

65. Rüegg, I.; Hafner, T.; Bucheli-Witschel, M.; Egli, T. Dynamics of benzene and toluene degradation in Pseudomonas putida F1 in the presence of the alternative substrate succinate. Eng. Life Sci. 2007, 7, 331-342. [CrossRef]

66. Yu, H.; Kim, B.J.; Rittmann, B.E. The roles of intermediates in biodegradation of benzene, toluene, and p-xylene by Pseudomonas putida F1. Biodegradation 2001, 12, 455-463. [CrossRef] [PubMed]

67. Shi, Y.; Chai, L.; Tang, C.; Yang, Z.; Zhang, H.; Chen, R.; Chen, Y.; Zheng, Y. Characterization and genomic analysis of kraft lignin biodegradation by the beta-proteobacterium Cupriavidus basilensis B-8. Biotechnol. Biofuels. 2013, 6, 1-4. [CrossRef] [PubMed] 
68. Moriuchi, R.; Dohra, H.; Kanesaki, Y.; Ogawa, N. Transcriptome differences between Cupriavidus necator NH9 grown with 3-chlorobenzoate and that grown with benzoate. Biosci. Biotechnol. Biochem. 2021, 85, 1546-1561. [CrossRef]

69. Lykidis, A.; Perez-Pantoja, D.; Ledger, T.; Mavromatis, K.; Anderson, I.J.; Ivanova, N.N.; Hooper, S.D.; Lapidus, A.; Lucas, S.; Gonzalez, B.; et al. The complete multipartite genome sequence of Cupriavidus necator JMP134, a versatile pollutant degrader. PLOS ONE 2010, 5, e9729. [CrossRef]

70. Sauret-Ignazi, G.; Gagnon, J.; Béguin, C.; Barrelle, M.; Markowicz, Y.; Pelmont, J.; Toussaint, A. Characterization of a chromosomally encoded catechol 1,2-dioxygenase (E.C. 1.13.11.1) from Alcaligenes eutrophus CH34. Arch. Microbiol. 1996, $166,42-50$. [CrossRef]

71. Han, L.; Chen, S.; Zhou, J. Expression and cloning of cat $A$ encoding a catechol 1,2-dioxygenase from the 2,4-D-degrading strain Cupriavidus campinensis BJ71. Prep. Biochem. Biotechnol. 2020, 50, 486-493. [CrossRef]

72. Pérez-Pantoja, D.; Ledger, T.; Pieper, D.H.; González, B. Efficient turnover of chlorocatechols is essential for growth of Ralstonia eutropha JMP134 (pJP4) in 3-chlorobenzoic acid. J. Bacteriol. 2003, 185, 1534-1542. [CrossRef]

73. Donoso, R.A.; Ruiz, D.; Gárate-Castro, C.; Villegas, P.; González-Pastor, J.E.; de Lorenzo, V.; González, B.; Pérez-Pantoja, D. Identification of a self-sufficient cytochrome P450 monooxygenase from Cupriavidus pinatubonensis JMP134 involved in 2hydroxyphenylacetic acid catabolism, via homogentisate pathway. Microb. Biotechnol. 2021, 14, 1944-1960. [CrossRef]

74. Cafaro, V.; Izzo, V.; Scognamiglio, R.; Notomista, E.; Capasso, P.; Casbarra, A.; Pucci, P.; Di Donato, A. Phenol hydroxylase and toluene/o-xylene monooxygenase from Pseudomonas stutzeri OX1: Interplay between Two Enzymes. Appl. Environ. Microbiol. 2004, 70, 2211-2219. [CrossRef]

75. Shields, M.S.; Montgomery, S.O.; Chapman, P.J.; Cuskey, S.M.; Pritchard, P.H. Novel pathway of toluene catabolism in the trichloroethylene-degrading bacterium G4. App. Environ. Microbiol. 1989, 55, 1624-1629. [CrossRef]

76. Hur, H.G.; Newman, L.M.; Wackett, L.P.; Sadowsky, M.J. Toluene 2-monooxygenase-dependent growth of Burkholderia cepacia G4/PR1 on diethyl ether. Appl. Environ. Microbiol. 1997, 63, 1606-1609. [CrossRef] [PubMed]

77. O'Sullivan, L.A.; Weightman, A.J.; Jones, T.H.; Marchbank, A.M.; Tiedje, J.M.; Mahenthiralingam, E. Identifying the genetic basis of ecologically and biotechnologically useful functions of the bacterium Burkholderia vietnamiensis. Environ. Microbiol. 2007, 9, 1017-1034. [CrossRef] [PubMed]

78. Mahendra, S.; Alvarez-Cohen, L. Kinetics of 1,4-dioxane biodegradation by monooxygenase-expressing bacteria. Environ. Sci. Technol. 2006, 40, 5435-5442. [CrossRef] [PubMed]

79. Clay, K.M.C.; Fox, B.G.; Steffan, R.J. Toluene monooxygenase-catalyzed epoxidation of alkenes. Appl. Environ. Microbiol. 2000, 66, 1877-1882. [CrossRef]

80. Tao, Y.; Fishman, A.; Bentley, W.E.; Wood, T.K. Oxidation of benzene to phenol, catechol, and 1,2,3-trihydroxybenzene by toluene 4-monooxygenase of Pseudomonas mendocina KR1 and toluene 3-monooxygenase of Ralstonia pickettii PKO1. App. Environ. Microbiol. 2004, 70, 3814-3820. [CrossRef] [PubMed]

81. Hamzah, R.Y.; Al-Baharna, B.S. Catechol ring-cleavage in Pseudomonas cepacia: The simultaneous induction of ortho and meta pathways. Appl. Microbiol. Biotechnol. 1994, 41, 250-256. [CrossRef]

82. Cao, B.; Geng, A.; Loh, K.C. Induction of ortho and meta-cleavage pathways in Pseudomonas in biodegradation of high benzoate concentration: MS identification of catabolic enzymes. Appl. Microbiol. Biotechnol. 2008, 81, 99-107. [CrossRef]

83. Von Rozycki, T.; Nies, D. Cupriavidus metallidurans: Evolution of a metal-resistant bacterium. Antonie Van Leeuwenhoek 2009, 96, 115-139. [CrossRef]

84. Scherer, J.; Nies, D. CzcP is a novel efflux system contributing to transition metal resistance in Cupriavidus metallidurans CH34. Mol. Microbiol. 2009, 73, 601-621. [CrossRef]

85. Wu, X.; Monchy, S.; Taghavi, S.; Zhu, W.; Ramos, J.; van der Lelie, D. Comparative genomics and functional analysis of niche-specific adaptation in Pseudomonas putida. FEMS Microbio. Rev. 2011, 35, 299-323. [CrossRef]

86. Agulló, L.; Romero-Silva, M.J.; Domenech, M.; Seeger, M. $p$-Cymene promotes its catabolism through the $p$-cymene and the $p$-cumate pathways, activates a stress response and reduces the biofilm formation in Burkholderia xenovorans LB400. PLoS ONE 2017, 12, e0169544. [CrossRef]

87. Heipieper, H.J.; Martínez, P.M. Toxicity of hydrocarbons to microorganisms. In Cellular Ecophysiology of Microbe: Hydrocarbon and Lipid Interactions; Krell, T., Ed.; Springer: Berlin/Heidelberg, Germany, 2018; pp. 335-344. [CrossRef]

88. Nies, D.H. Microbial heavy-metal resistance. Appl. Microbiol. Biotechnol. 1999, 51, 730-750. [CrossRef] [PubMed]

89. Kivisaar, M. The effect of cellular redox status on the evolvability of new catabolic pathways. Mbio 2018, 9, 10-13. [CrossRef]

90. Horn, J.M.; Brunke, M.; Deckwer, W.D.; Timmis, K.N. Pseudomonas putida strains which constitutively overexpress mercury resistance for biodetoxification of organomercurial pollutants. Appl. Environ. Microb. 1994, 60, 357-362. [CrossRef] [PubMed]

91. Velázquez, F.; De Lorenzo, V.; Valls, M. The m-xylene biodegradation capacity of Pseudomonas putida mt-2 is submitted to adaptation to abiotic stresses: Evidence from expression profiling of xyl genes. Environ. Microbiol. 2006, 8, 591-602. [CrossRef]

92. Chillappagari, S.; Seubert, A.; Trip, H.; Kuipers, O.P.; Marahiel, M.A.; Miethke, M. Copper stress affects iron homeostasis by destabilizing iron-sulfur cluster formation in Bacillus subtilis. J. Bacteriol. 2010, 192, 2512-2524. [CrossRef] [PubMed]

93. LaVoie, S.P.; Summers, A.O. Transcriptional responses of Escherichia coli during recovery from inorganic or organic mercury exposure. BMC Genom. 2018, 19, 1-24. [CrossRef]

94. Li, J.; Ren, X.; Fan, B.; Huang, Z.; Wang, W.; Zhou, H.; Lou, Z.; Ding, H.; Lyu, J.; Tan, G. Zinc toxicity and iron-sulfur cluster biogenesis in Escherichia coli. Appl. Environ. Microbiol. 2019, 85, 1-36. [CrossRef] 
95. Ferianc, P.; Farewell, A.; Nyström, T. The cadmium-stress stimulon of Escherichia coli K-12. Microbiology 1998, 144, 1045-1050. [CrossRef]

96. Helbig, K.; Bleuel, C.; Krauss, G.J.; Nies, D.H. Glutathione and transition-metal homeostasis in Escherichia coli. J. Bacteriol. 2008, 190, 5431-5438. [CrossRef] [PubMed]

97. Wang, A.; Crowley, D.E. Global gene expression responses to cadmium toxicity in Escherichia coli. J. Bacteriol. 2005, 187, 3259-3266. [CrossRef] [PubMed]

98. Guzik, U.; Hupert-Kocurek, K.; Sałek, K.; Wojcieszyńska, D. Influence of metal ions on bioremediation activity of protocatechuate 3,4-dioxygenase from Stenotrophomonas maltophilia KB2. World J. Microbiol. Biotechnol. 2012, 29, 267-273. [CrossRef] [PubMed]

99. Hupert-Kocurek, K.; Saczyńska, A.; Piotrowska-Seget, Z. Cadmium increases catechol 2,3-dioxygenase activity in Variovorax sp. 12S, a metal-tolerant and phenol-degrading strain. Antonie Leeuwenhoek 2013, 104, 845-853. [CrossRef]

100. Lipscomb, J.D. Mechanism of extradiol aromatic ring-cleaving dioxygenases. Curr. Opin. Struct. Biol. 2008, 18, 644-649. [CrossRef]

101. Jindrová, E.; Chocová, M.; Demnerová, K.; Brenner, V. Bacterial aerobic degradation of benzene, toluene, ethylbenzene and xylene. Folia Microbiol. 2002, 47, 83-93. [CrossRef] 